\title{
EXPLORING LOCATION DETERMINANTS OF ASIA'S UNIQUE BEVERAGE SHOPS BASED ON A HYBRID MADM MODEL
}

\author{
Sheng-Hau LIN (iD ${ }^{1}$, Chih-Chen HSU², Taiyang ZHONG ${ }^{3}$, Xiwei HE ${ }^{4}$, Jia-Hsuan $\mathrm{LI}^{5}$, \\ Gwo-Hshiung TZENG ${ }^{6}$, Jing-Chzi HSIEH7,* \\ ${ }^{1}$ Law School, Ningbo University, Ningbo City, China \\ ${ }^{2}$ Department of Business Administration, Soochow University, Taipei City, Taiwan \\ ${ }^{3}$ School of Geography and Ocean Science, Nanjing University, Nanjing City, China \\ 4 State Key Laboratory of Pollution Control and Resource Reuse, School of the Environment, \\ Nanjing University, Nanjing City, China \\ ${ }^{5}$ School of Geographical Sciences, Nanjing University of Information Science and Technology, \\ Nanjing City, China \\ ${ }^{6}$ Graduate Institute of Urban Planning, College of Public Affairs, National Taipei University, \\ New Taipei City, Taiwan \\ 7 Department of Land Management, College of Construction and Development, Feng Chia University, \\ Taichung City, Taiwan
}

Received 31 October 2020; accepted 22 February 2021

\begin{abstract}
Identifying relevant location determinants is a good starting point for shop operators, help to increase profitability and, thus, avoiding business failure. Traditional Analytic Hierarchy Process (AHP) or the Analytic Network Process (ANP) have shortages that require improvement. Herein, Decision-Making Trial and Evaluation Laboratory (DEMATEL), ANP based on DEMATEL (DANP), and modified Vlse Kriterijumska Optimizacija I Kompromisno Resenje (modified VIKOR) are used to construct a hybrid multiple-attribute decision making (MADM) model, encompassing three dimensions and thirteen criteria in exploring the location determinants of Asia's unique Bubble Tea Shops (BTSs) and to evaluate three preselected alternatives in Nanjing, China. The empirical findings of the DEMATEL method reveal that traffic traits $\left(D_{1}\right)$ and site traits $\left(D_{2}\right)$ are critical to BTSs, and that once these are enhanced, shop traits $\left(D_{3}\right)$ are also improved. Criteria deemed as important, based on the DEMATEL and DANP methodology, are (in descending order): proximity to a street corner $\left(C_{2}\right)$, proximity to public transportation systems $\left(C_{1}\right)$, road width $\left(C_{3}\right)$, proximity to communities $\left(C_{5}\right)$, proximity to commercial areas $\left(C_{6}\right)$, types of shop $\left(C_{9}\right)$, and proximity to schools $\left(C_{7}\right)$. Different decision-making rankings among alternatives are indicated based upon the modified VIKOR method and corresponding strategies for improvement are presented.
\end{abstract}

Keywords: Bubble Tea Shop (BTS), location determinants, Decision-Making Trial and Evaluation Laboratory (DEMATEL), Analytic Network Process based on DEMATEL (DANP), modified Vlse Kriterijumska Optimizacija I Kompromisno Resenje (modified VIKOR).

\section{Introduction}

As a key factor in the success of long-term strategic decisions, location determinants have received extensive attention in the research on food outlets, such as restaurants (Tzeng et al., 2002; Park \& Khan, 2006; Dock et al., 2015; Chen \& Tsai, 2016; Yang et al., 2017), convenience stores (Kuo et al., 2002), and the food retail industry (Sevtsuk, 2014; Ylldız \& Tüysüz, 2019). As an important feature in people's daily dietary routines, beverage shops-such as coffee shops (Wibisono \& Marella, 2020) and tea houses in Europe (Chen et al., 2018)-have also been examined. A series of retail location theories-including spatial interaction theory (Reilly, 1929, 1931), central location theory (Christaller, 1933, 1966), and bid-rent theory (Alonso, 1964)-have been used to explore the complex relationship between consumers' demands, accessibility, and retail location. Whether it concerns a chain enterprise or a single store, proper decision-making about an establishment's location can help expand the venture's market of concern in order to attract more customers, increase market share

*Corresponding author. E-mails: jchsieh@fcu.edu.tw, chenyi.hsieh@gmail.com 
and subsequent profitability, shorten the period needed to repay fixed capital investments (Chou et al., 2008), and improve customer loyalty via convenience (Yang et al., 2017). Consequently, a convincing evaluation of the store location determinants is a good starting point for operators.

Various multi-attribute decision-making (MADM) models have been applied in the efforts to solve location decision-making problems, which are often shaped by multiple objectives and conflicts of interest (Chou et al., 2008; Chen et al., 2018). This is because the traditional decision-making methods for location selection, such as the checklist method, simulation method, and regression model-are based on the knowledge and experience of managers; these methods can only provide decision-makers with a set of steps to take in solving the problem, without taking into account the relationship between the decision-making factors (Kuo et al., 2002). MADM models that can simultaneously cover qualitative and quantitative indicators are considered suitable for identifying and exploring location determinants (Tzeng et al., 2002; Ylldız \& Tüysüz, 2019). Among the many MADM models, the Analytic Hierarchy Process (AHP), as developed by Saaty (1980), and its extended variant have commonly been used to explore the various location selections relevant to the food retail industry (Kuo et al., 1999, 2002; Tzeng et al., 2002; Ho et al., 2013; Ylldız \& Tüysüz, 2019). In this regard, Tzeng et al's paper (2002) is a representative study in terms of restaurant operators' location selection. In addition, the Analytic Network Process (ANP) (Saaty, 1986) has been utilized to explore location selection decisions in the retail industry (Tolga et al., 2013) and among cafes (Wibisono \& Marella, 2020). Moreover, a data mining framework based on rough set theory has been used in relation to the decision-making of restaurant locations (Chen \& Tsai, 2016), and evaluations based on the distance from the average solution (EDAS) method and the weighted aggregated sum product assessment with normalization (WASPAS-N) method have been used to explore the factors determining the location of teahouses (Chen et al., 2018). Although these studies have provided a favorable foundation, these MADM methods carry some unrealistic assumptions that do not take into consideration the relationships between the factors relating to a location's selection (Tzeng \& Shen, 2017; Shen \& Tzeng, 2018; Liu et al., 2018a; Chen et al., 2019; Peng \& Tzeng, 2019; Lin et al., 2021). Hence, reliance on traditional methods to identify and evaluate a location's determining factors is not sufficiently persuasive. Thus, the primary purpose of the present study is to address this issue. The research objects of this study are "hand-shake beverages shops" (a Taiwanese term), also known as "bubble tea shops" (a Mainland China term, hereinafter abbreviated to as BTSs), which sell various types of hand-tea beverages and are common in Asia, especially China, Taiwan, and Hong Kong (see Figure 1).

BTSs are quite different from teahouses in Europe (Chen et al., 2018), providing drinks made from different types of tea (the most common being black tea, green tea, clear tea, and oolong tea), sugars (fructose, sucrose, or honey), sweetened ingredients (pearls made from tapioca flour, weak tinctures, and fine grass, for example), milk (creamer or milk), and fruit (fresh fruit and conserves). The degree of sweetness and temperature of the drink can be made according to the customer's needs. Of these variations, and thanks to contemporary globalization, "Bubble/Pearl Milk Tea" (also known as "Oriental Cola" in Taiwan; Lan, 2007) is the best-known beverage normally available at BTSs (Lin \& Tzeng, 2010). After decades of rapid expansion, BTSs, which originated in Taiwan in the 1980s (Fortune Business Insights [FBI], 2019), can be found in many countries, including Singapore, Malaysia, Indonesia, Hong Kong, Japan, South Korea, the United States, Australia, and New Zealand (Lin \& Tzeng, 2010) and have become a daily feature in the dietary regimens of urban residents in Taiwan and Mainland China. Statistics indicate that the primary consumer groups of BTSs in Beijing, as of July 2018, were the post-1980s and 1990s youth demographics, accounting for $88 \%$ of business conducted (Ran, 2018). Currently, 18,142 BTSs operate in Taiwan, reaching cumulative business sales of NT $\$ 52$ billion (Ministry of Finance, R.O.C., 2018), which is much higher than the 3,403 cafes and the

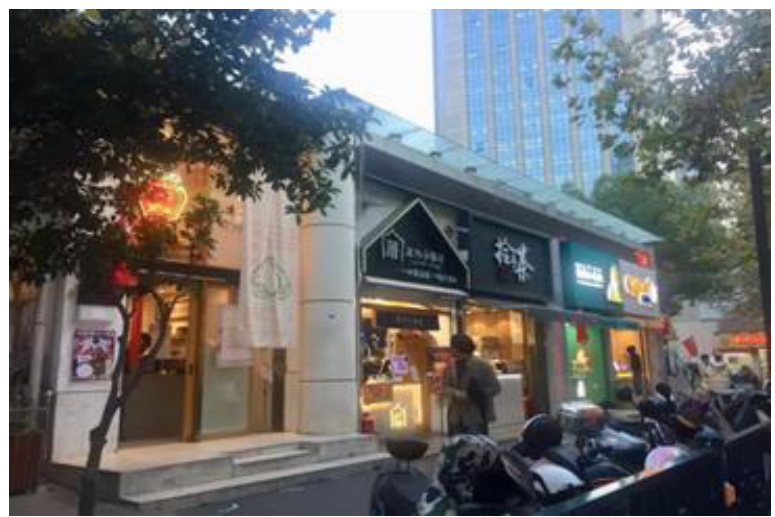

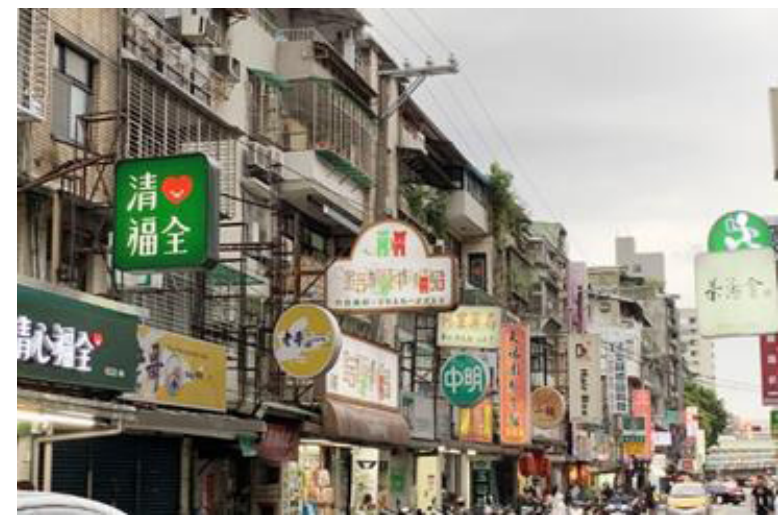

Note: Pictures were collected by Tsai (2019) and the research team on August, 2019.

Figure 1. The BTSs on Chinese urban streets such as Taipei of Taiwan (left side) and Nanjing of Mainland China (right side) 
12,000 convenience stores in the country (Tsai, 2019). In Mainland China, more than 180,000 BTSs were operating in 2017; furthermore, many cities are still experiencing a growth in the number of BTSs, creating huge competition among the BTS stores. The flourishing of and competition in the BTS market render this study important by virtue of its efforts to conduct a good ex-ante evaluation under conditions of limited financial resources and promote BTS businesses' sustainability operation.

Given the shortage of models concerning the location determinants of BTSs, this study attempts to address the questions concerning BTS location determinants via a hybrid MADM model. In summary, this study will first explore the interaction between the determinants related to the choice of a BTS's location, making use of the Decision-Making Trial and Evaluation Laboratory (DEMATEL) method and combining the weights obtained via the DEMATEL-based ANP method (DANP) to identify the critical location determinants of BTSs. In addition, this study evaluates three pre-selected alternatives for BTSs in Nanjing, China, via the DANP and a modified Vlse Kriterijumska Optimizacija I Kompromisno Resenje method (modified VIKOR). The remaining sections are arranged as follows: section 1 proposes the selected location determinants concerning BTSs; section 2 provides detailed descriptions of three pre-selected cases and the modeling procedures of the MADM; section 3 presents the empirical findings; section 4 presents the discussion, and lastly section indicates the conclusion, and research outlook.

\section{Constructing an evaluation framework for the location determinants of BTSs}

"Location, location, location" is a classic truism often repeated in real estate investment and management; hence, exploring location determination/selection is appropriate for revealing key factors in successful retail operations. The location of retail stores provides retailers with competitive and unique advantages, making the choice of location an important strategic decision that carries great importance to retailers' overall success. Furthermore, such a choice depends on the location's convenience for serving customers and on how many customers the business can attract, which have a significant impact on the store's market share and profitability (Tzeng et al., 2002; Ylldız \& Tüysüz, 2019). Since 1929, a series of classic theories exploring the location and spatial distribution of the retail industry have been proposed, including spatial interaction theory (Reilly, 1929, 1931), Hotelling's linear city model (Hotelling, 1929), central place theory (Christaller, 1933, 1966), and even bid-rent theory (Alonso, 1964). These theories aim to identify the factors affecting retail locations by exploring the relationship between consumers' demands and accessibility as a core consideration.

As the predecessor of the gravity type model, spatial interaction theory assumes that customers may be presented with a trade-off between attractiveness and distance barrier effects when it comes to the specific products or services provided by a store. As such, site-relevant factors such as store size, price, service level, and attractiveness need to be considered (Chen \& Tsai, 2016). The principle of minimum differentiation proposed by Hotelling (1929) places greater emphasis on the influence of clustering effects, indicating that the proximity to competitors in the geographical area is an indicator of the attractiveness and competitiveness of the region (Chou et al., 2008); that is to say, proximity to competitors is more critical than proximity to customers (Prayag et al., 2012). According to central location theory, retail location is determined by the "range" of the maximum distance that consumers are willing to travel in order to obtain goods; thus, the theory carries the implicit assumption that a store should be located in an area with a large population and be within an acceptable traveling distance (Prayag et al., 2012). The bid-rent theory identifies a positive relationship between rent and distance from the city center, meaning that a location's rent increases the closer it is to the city center, greater proximity being accompanied by greater opportunities to serve a larger number of well-known customers. These elements are also regarded as good indicators of performance and competitiveness (Yıldız \& Tüysüz, 2019).

Based on the above theoretical elements, the existing literature employing MADM to explore the location determinants relevant to food stores (such as restaurants, food retailers, and beverage shops) has provided a valuable evaluative framework. Fisher (1997) has proposed a comprehensive model for selecting restaurant franchisees, including location demographics, transportation support, accessibility and visibility, physical attributes, traffic flow, clusters of competitive stores, and economic indicators. Tzeng et al. (2002) adopted the AHP in presenting a restaurant's decision-making framework, covering $11 \mathrm{sub}$-dimensions across five major categories, covering economic, transportation, competition, commercial, and environmental domains. Similarly, Park and Khan (2006) used Delphi technology to examine a total of 56 US franchise restaurant locations using six dimensions, namely, overall location, site location, demographics, traffic information, competition, and cost. Chen and Tsai (2016) proposed a restaurant location model based upon data mining and a range of dimensions such as demographics, market conditions, store fees, store conditions, and accessibility. Using the hesitant analysis hierarchy method (H-AHP) and gray correlation analysis (GRA), Ylldız and Tüysüz (2019) constructed a multi-criteria strategic location decision-making model for the food retail industry with the spatial scale of the city in mind. Some research has also explored the decision framework employed by beverage shops. Chen et al. (2018), for example, utilized the distance from average solution (EDAS) method and the weighted aggregated sum product assessment with normalization (WASPAS-N) method, along with relevant criteria, to develop a decision model for teahouse locations. The criteria relevant to Chen et al's model included rent, property area, distance 
to landscape, public transportation, pedestrian flow, parking flow, presence of competitors, crime rates, distance to public facilities, outdoor advertising, and distance to refuse removal services. Recently, Wibisono and Marella (2020) have utilized the AHP and ANP methods to discuss the location decision-making for cafes, including relevant criteria such as location characteristics, demography, cost, physical features, and competition.

Given the foundation presented by the existing literature, traffic traits $\left(D_{1}\right)$, site traits $\left(D_{2}\right)$, and shop traits $\left(D_{3}\right)$, cumulatively comprising a total of 13 relevant criteria, are proposed in this study as determinants in decisions about BTS store locations (for more details, see Table 1). Although the business acumen of the operator is an important factor in explaining the success of restaurant operations (Parsa et al., 2005; Chathoth \& Olsen, 2007; John et al., 2015), this study excludes this factor in order to focus the research on location-centric determinants of BTS (Tzeng et al., 2002; Chen \& Tsai, 2016; Chen et al., 2018). The 13 selected criteria are explained below.

\subsection{Traffic traits $\left(D_{1}\right)$}

Accessibility has played a critical role in the choice of location. Retail store owners often find convenient locations and increase their exposure to potential customers (Brown, 1993). Greater convenience in public transportation, such as subways, buses, and trolleybuses, will affect accessibility for consumers (Austin et al., 2005; Widener et al., 2017; Chen et al., 2018; Murphy et al., 2018; Wu et al., 2018). Tzeng et al. (2002) have also pointed out that restaurant operators pay greater attention to transportation than other factors. Compared to the distance from bus stops, the distance from subway stations has a more significant impact on the concentration of retail or food service industries (Sevtsuk, 2014). A study from Taipei, which echoes the bid-rent theory of Alonso (1964), has also found that being located near newly built subway stations will incur a greater probability of commercial gentrification, meaning that an area is more easily transformed into retail and restaurant services (Lin \& Yang, 2019). Chen et al. (2018) have also found that high pedestrian flows and a high frequency of public transportation were advantageous in a teahouse's location choice. Thus, it can be predicted that "proximity to public transportation systems" $\left(C_{1}\right)$ is regarded as appropriate as one of the criteria for location determinants of BTSs.

On the other hand, distance to a street corner and road width also affect consumers' access to a shop/location.

Through research on retail locations in Cambridge and Somerville (UK) and Massachusetts (USA), Sevtsuk (2014) found that if a shop can directly access more streets, it will attract more people and subsequently enjoy greater accessibility from the additional route connections. This factor was taken into account in the location selection of convenience stores by Kuo et al. $(1999,2002)$ and for restaurants by Chen and Tsai (2016). In addition, road width is considered to affect customers' behavior patterns, with studies highlighting the trend of fast-food restaurants and donut shops typically facing a main road (Smith, 1983, 1985). Oh et al. (2015) have also found that the road's width in front of a Korean restaurant chain outlet positively correlates with the store's sales. Sufficient sidewalk space can accommodate more consumers and promote the complementarity and purchase of "comparative goods", such as items from other restaurants (Sevtsuk, 2014). Hence, "proximity to a street corner" $\left(C_{2}\right)$ and "road width" $\left(C_{3}\right)$ are both selected for this dimension.

\subsection{Site traits $\left(D_{2}\right)$}

The site itself has always been critical in explaining the choice of location for food retail or restaurants (John et al., 2015). A series of retail location theories have clearly shown that restaurants' location decision-making revolves around the consumer base (Zhai et al., 2015; Xu et al., 2019). Yang et al. (2017) found that leading fullservice chains prefer locations in urbanized areas, whereas fast-food chains-such as McDonald's and Pizza Hut-may prefer sites in the urban areas of smaller towns. In addition, the distance from public facilities also indicates the potential for consumption, which is also a commonly selected factor identified throughout the literature (Kuo et al., 1999, 2002; Tzeng et al., 2002; Ho et al., 2013; Chen \& Tsai, 2016 Chen et al., 2018).

Although most of the literature related to restaurant location selection has recognized commercial areas as a necessary consideration (Tzeng et al., 2002; Zhang \& Xu, 2009; Sevtsuk, 2014; Chen et al., 2018; Xu et al., 2019), restaurants are also often observed around neighborhoods or school areas. This has received a substantial amount of attention in public health research as it relates to the food environment. Studies have found a positive relationship between outlet densities of fast-food stores near a community and purchase frequency (He et al., 2012; Smith et al., 2013). Communities located near a store with sugar-sweetened beverages (SSBs) see an increase in SSB consumption frequency (Adjoian et al., 2014; Duran et al., 2016). Studies have also shown that the density of fast-food stores around schools has increased over time (Day et al., 2015) and that schools near areas with high population densities and commercial areas have more clusters of fast-food outlets and convenience stores (Day \& Pearce, 2011; Engler-Stringer et al., 2014; Yang et al., 2017). It is also important to note that the "food delivery industry" is expanding rapidly throughout China-and, more recently, in Taiwan-and is affecting food purchasing behavior (Maimaiti et al., 2018). It was found that $41.86 \%$ of food retail stores provide food delivery in the region of the West Lake in Hangzhou city (Maimaiti et al., 2020). Food delivery will expand the existing customer base through a limited number of locations and expand the scope of services, which must be carefully evaluated. Overall, "proximity to public facilities" $\left(C_{4}\right)$, "proximity to communities" $\left(C_{5}\right)$, "proximity to commercial areas" $\left(C_{6}\right)$, and "proximity to schools" $\left(C_{7}\right)$ are all suitable criteria for site traits as they relate to BTS location choice. 
Table 1. Proposed dimension/criteria for location determinations of BTS

\begin{tabular}{|c|c|c|c|}
\hline Dimension & Criteria & Description & Reference \\
\hline \multirow[t]{3}{*}{$\begin{array}{l}\text { Traffic traits } \\
\left(D_{1}\right)\end{array}$} & $\begin{array}{l}\text { proximity } \\
\text { to public } \\
\text { transportation } \\
\text { system }\left(C_{1}\right)\end{array}$ & $\begin{array}{l}\text { Shops with more subway stations and a larger } \\
\text { number of bus lines within a certain range have better } \\
\text { accessibility to transportation, and will likely attract } \\
\text { more potential customers }\end{array}$ & $\begin{array}{l}\text { Chen and Tsai (2016); Chen et al. (2018) } \\
\text { Ho et al. (2013); Kuo et al. (1999); Kuo } \\
\text { et al. (2002); Tzeng et al. (2002); Oh et al. } \\
\text { (2015); Wibisono and Marella (2020) }\end{array}$ \\
\hline & $\begin{array}{l}\text { proximity to a } \\
\text { street corner } \\
\left(C_{2}\right)\end{array}$ & $\begin{array}{l}\text { Shops near a street corner will likely attract more } \\
\text { potential customers }\end{array}$ & $\begin{array}{l}\text { Chen and Tsai (2016); Kuo et al. (1999); } \\
\text { Kuo et al. (2002); Tzeng et al. (2002) }\end{array}$ \\
\hline & $\begin{array}{l}\text { road width } \\
\left(C_{3}\right)\end{array}$ & $\begin{array}{l}\text { Shop facing a wide road will likely attract more } \\
\text { potential customers as more vehicles and pedestrians } \\
\text { are likely to pass }\end{array}$ & $\begin{array}{l}\text { Ho et al. (2013); Kuo et al. (1999); Kuo } \\
\text { et al. (2002); Tzeng et al. (2002); Oh et al. } \\
\text { (2015) }\end{array}$ \\
\hline \multirow[t]{5}{*}{$\begin{array}{l}\text { Site traits } \\
\left(D_{2}\right)\end{array}$} & $\begin{array}{l}\text { proximity to } \\
\text { public facilities } \\
\left(C_{4}\right)\end{array}$ & $\begin{array}{l}\text { Shops near community centers, arts and cultural } \\
\text { centers, stadiums and public libraries will likely attract } \\
\text { more potential consumers and expand its range via } \\
\text { food delivery systems }\end{array}$ & $\begin{array}{l}\text { Chen and Tsai (2016); Chen et al. (2018); } \\
\text { Ho et al. (2013); Kuo et al. (1999); Kuo } \\
\text { et al. (2002); Wibisono and Marella (2020) }\end{array}$ \\
\hline & $\begin{array}{l}\text { proximity to } \\
\text { the community } \\
\left(C_{5}\right)\end{array}$ & $\begin{array}{l}\text { Shops located in, or near larger communities will } \\
\text { likely attract more potential consumers and expand its } \\
\text { range via food delivery systems }\end{array}$ & $\begin{array}{l}\text { Chen and Tsai (2016); Chen et al. (2018); } \\
\text { Duran et al. (2016); He et al. (2012); } \\
\text { Maimaiti et al. (2018, 2020); Prayag et al. } \\
\text { (2012); Qin et al. (2019) }\end{array}$ \\
\hline & $\begin{array}{l}\text { proximity to } \\
\text { commercial } \\
\text { areas }\left(C_{6}\right)\end{array}$ & $\begin{array}{l}\text { Shops located in, or near larger commercial areas will } \\
\text { likely attract more potential consumers and expand its } \\
\text { range via food delivery systems }\end{array}$ & $\begin{array}{l}\text { Chen and Tsai (2016); Chen et al. (2018) } \\
\text { Ho et al. (2013); Kuo et al. (1999); Kuo } \\
\text { et al. (2002); Maimaiti et al. (2018, 2020); } \\
\text { Prayag et al. (2012); Tzeng et al. (2002); } \\
\text { Wibisono and Marella (2020) }\end{array}$ \\
\hline & $\begin{array}{l}\text { proximity to } \\
\text { schools }\left(C_{7}\right)\end{array}$ & $\begin{array}{l}\text { Shops located in school areas, such as University } \\
\text { towns or near larger schools, will likely attract more } \\
\text { potential consumers and expand its range via food } \\
\text { delivery systems }\end{array}$ & $\begin{array}{l}\text { Chiang et al. (2011); Cutumisu et al. } \\
\text { (2017); Day et al. (2015); He et al. (2012) } \\
\text { Kuo et al. (1999); Kuo et al. (2002); } \\
\text { Sevtsuk (2014); Qin et al. (2019) }\end{array}$ \\
\hline & $\begin{array}{l}\text { agglomeration } \\
\text { effect }\left(C_{8}\right)\end{array}$ & $\begin{array}{l}\text { Although areas with more BTSs may indicate a risk } \\
\text { of competition, it is more likely attract more potential } \\
\text { consumers and expand its range via food delivery } \\
\text { systems as agglomeration can aid customers in } \\
\text { choosing their beverage based on different tastes and } \\
\text { the atmosphere of the area/store }\end{array}$ & $\begin{array}{l}\text { Chen and Tsai (2016); Chen et al. (2018); } \\
\text { Ho et al. (2013); John et al. (2015); Kuo } \\
\text { et al. (1999); Kuo et al. (2002); Tzeng et al } \\
\text { (2002) }\end{array}$ \\
\hline \multirow[t]{5}{*}{$\begin{array}{l}\text { Shop traits } \\
\left(D_{3}\right)\end{array}$} & $\begin{array}{l}\text { types of shop } \\
\left(C_{9}\right)\end{array}$ & $\begin{array}{l}\text { Two types of shop, including the street shop and } \\
\text { shop in a department store, need to be considered. } \\
\text { Street stores attract more passers-by, while shops in } \\
\text { commercial complexes attract more consumer and } \\
\text { expand its range via food delivery systems }\end{array}$ & Xu et al. (2019); Yang et al. (2017) \\
\hline & $\begin{array}{l}\text { sizes of shop } \\
\left(C_{10}\right)\end{array}$ & $\begin{array}{l}\text { A shop's size must be able to support various usage } \\
\text { needs, such as shaking tea, brewing tea, and storage of } \\
\text { raw materials. The new generation of BTS may provide } \\
\text { more seats in the store, and a larger size may thus be } \\
\text { required }\end{array}$ & $\begin{array}{l}\text { Chen and Tsai (2016); Ho et al. (2013); } \\
\text { Kuo et al. (1999); Kuo et al. (2002); Yap } \\
\text { et al. (2019); Wibisono and Marella (2020) }\end{array}$ \\
\hline & rent $\left(C_{11}\right)$ & $\begin{array}{l}\text { Shops may incur a higher rent due to better } \\
\text { transportation and location conditions, larger size, or } \\
\text { visibility }\end{array}$ & $\begin{array}{l}\text { Chen and Tsai (2016); Chen et al. (2018); } \\
\text { Day et al. (2015); Fraser et al. (2010); } \\
\text { Fleischhacker et al. (2013); Ho et al. } \\
\text { (2013); Yap et al. (2019); Wibisono and } \\
\text { Marella (2020) }\end{array}$ \\
\hline & $\begin{array}{l}\text { business hours } \\
\left(C_{12}\right)\end{array}$ & $\begin{array}{l}\text { Shops with longer business hours have more time to } \\
\text { supply tea to consumers and are located in business } \\
\text { districts with similarly long total business hours }\end{array}$ & Oh et al. (2015); Chen and Tsai (2016) \\
\hline & visibility $\left(C_{13}\right)$ & $\begin{array}{l}\text { Shops with strong visibility, such as those located at } \\
\text { the core of the main street or commercial complex, } \\
\text { will increase their visibility and will be enhanced via } \\
\text { billboard advertisements }\end{array}$ & $\begin{array}{l}\text { Chen and Tsai (2016); Chen et al. (2018); } \\
\text { Kuo et al. (1999); Kuo et al. (2002); } \\
\text { Wibisono and Marella (2020) }\end{array}$ \\
\hline
\end{tabular}


Agglomeration effects should also be considered in terms of location determinants. Hotelling (1929) has emphasized the presence of agglomeration effects in the retail industry, demonstrating that proximity to competitors is an indicator of attractiveness and competitiveness (Chen \& Tsai, 2016). Eaton and Lipsey (1975) have also considered the agglomeration of homogeneous stores as a mechanism through which consumers can compare prices and products to reduce search costs. The clustering of restaurants in the Central Business District of Hamilton, New Zealand, exemplifies the notion that clustering not only can promote the sharing of facilities and promotion costs but can also provide multiple options for consumers, thereby reducing the search costs and increasing the attraction of restaurants and the area in general (Prayag et al., 2012). Empirical research conducted in Cambridge and Somerville (UK) and Massachusetts (USA) found that restaurants and bars were more concentrated than were clothing, clothing accessories, or food retail stores (such as supermarkets) (Sevtsuk, 2014). This is because restaurants and bars provide "comparative goods," and agglomeration can help customers decide based on different tastes or atmospheres (among others), hence saving time costs. However, agglomeration may face strong competition risks (John et al., 2015), and many studies have included competitors as a consideration in site selection (Kuo et al., 1999, 2002; Tzeng et al., 2002; Prayag et al., 2012; Ho et al., 2013; Chen \& Tsai, 2016; Chen et al., 2018). Although most of the BTSs offer similar tea-mixed beverages at first glance, they still have some differences, such as in taste and place, among others, and the aggregation phenomenon is common (see Figure 1). Therefore, the "aggregation effect" $\left(C_{8}\right)$ is also selected as a criterion for site traits.

\subsection{Shop traits $\left(D_{3}\right)$}

In addition to external factors, some criteria related to shops' physical conditions are also considered. As indicated by spatial interaction theory, the store's attributes have become one of the important trade-offs considered by consumers when purchasing goods (Prayag et al., 2012). A systematic review of the literature by Yap et al. (2019) also found that most of the academic research on location decision-making for retail facilities will include the store's size (space).

In China, large commercial complexes, such as department stores or shopping malls, are often important for driving urban development in fast-growing cities and providing food retail stores and restaurants to urban residents (Qin et al., 2019; Xu et al., 2019). Therefore, in addition to traditional types of shops on streets, outlets in commercial complexes or larger department stores are also considered a location choice. Chen and Tsai (2016) have also pointed out that a shop's size and visibility are the main considerations when evaluating restaurants' location. They have suggested that larger shops have greater performance potential in sales, especially when coupled with conditions of moderate population growth rate or lack of proximity to Mass Rapid Transit (MRT) stations or stops. Thus, "types of shop" $\left(C_{9}\right)$ and "size of shop" $\left(C_{10}\right)$ are both selected for this dimension.
In addition, the most prominent location determinant cannot be ignored: "rents." Higher rents often imply competitive bidding and often correlate with better location conditions (Alonso, 1964; Lin \& Yang, 2019). Tzeng et al. (2002) have also found that, from the perspective of experts, in addition to transportation costs, rents are the most important factor in location selection; high leasing costs may affect the ability to leverage operations, leading to the death of restaurants (John et al., 2015). Fastfood stores are often clustered around poor communities and their school district; this choice can be reasonably explained by the availability of low land prices or rents (Fraser et al., 2010; Fleischhacker et al., 2013; Day et al., 2015). Hence, "rent" $\left(C_{11}\right)$ is included as a criterion.

Additional features related to business performance include business hours and visibility. Oh et al. (2015) have shown that weekend hours are very important to a Korean family restaurant's operating performance due to the policy of working five days a week. A signboard's visibility will affect the likelihood of potential customers entering the store, which is also considered in the relevant literature (Kuo et al., 1999, 2002; Chen \& Tsai, 2016; Chen et al., 2018; Wibisono \& Marella, 2020). Hence, "business hours" $\left(C_{12}\right)$ and "visibility" $\left(C_{13}\right)$ have also been included.

\section{Three alternatives for potential evaluation and modelling procedures for a hybrid MADM model}

\subsection{Three alternatives in Nanjing for potential evaluation}

This study selects three pre-selected alternatives in Nanjing, Mainland China, as research cases in evaluating their effects on the choice of a BTS' location. Nanjing, as the capital of Jiangsu Province, makes up part of the core city group situated along the Yangtze River Delta (see Figure 2). At present, the city's population has reached 8.28 million, and eleven administrative regions, including: Gulou District, Qinhuai District, Xuanwu District, Jianye District, Yuhuatai

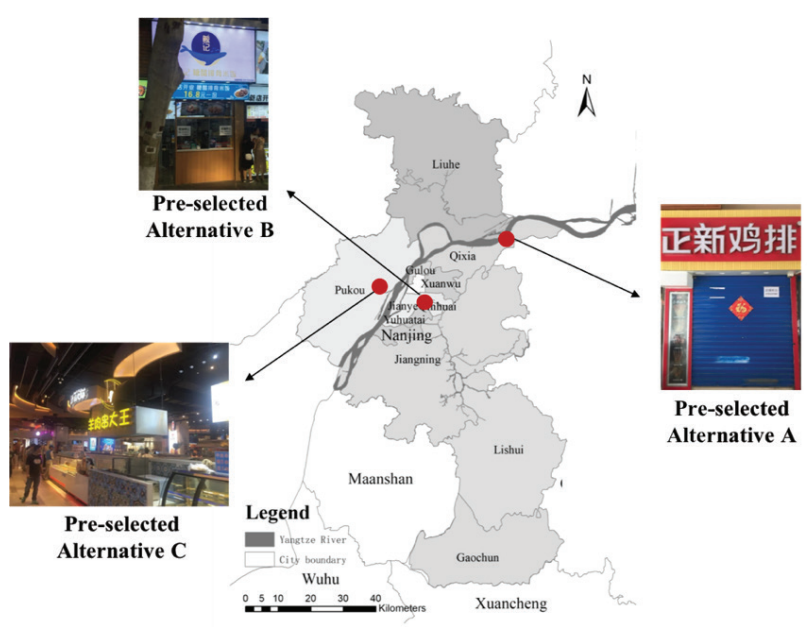

Note: Nanjing's map was collected by Shi et al. (2019)

Figure 2. The location distribution of three pre-selected alternatives in Nanjing 
District, Qixia District, Pukou District, Jiangning District, Liuhe District, Gaochun District and Lishui District (Qi et al., 2019). According to data from Dianping.com, 5,515 BTSs can be found in Nanjing (as of mid- June 2019).

The information concerning each criteria pertaining the three pre-selected alternatives - including pre-selected alternative A (located in Xianlin University town), preselected alternative B (located in the highest commercial grade zone in Qinhuai district), and pre-selected alterna- tive $\mathrm{C}$ (located in the new development zone in Pukou district) - was obtained by the research team between June and mid-July 2019. The Baidu Map (https://map.baidu. $\mathrm{com} /$ ) was utilized to measure the information related to traffic traits, while Dianping.com was utilized to confirm whether or not the area can be covered by food delivery services. Information related to the shops was obtained via field research. Please refer to Table 2 for a breakdown of the information collected pertaining to the three sites.

Table 2. Three alternatives in Nanjing for performance evaluation

\begin{tabular}{|c|c|c|c|c|}
\hline Dimension & Criteria & Alternative A & Alternative B & Alternative C \\
\hline \multicolumn{2}{|l|}{ Area } & $\begin{array}{l}\text { Xuezelu commercial area in } \\
\text { Xianlin University Town, } \\
\text { Qixia District }\end{array}$ & $\begin{array}{l}\text { Xinjiekou Commercial District in } \\
\text { Qinhuai District }\end{array}$ & $\begin{array}{l}\text { Jiangbei New District, Pukou } \\
\text { District }\end{array}$ \\
\hline \multirow[t]{3}{*}{$\begin{array}{l}\text { Traffic traits } \\
\left(D_{1}\right)\end{array}$} & $\begin{array}{l}\text { proximity } \\
\text { to public } \\
\text { transportation } \\
\text { system }\left(C_{1}\right) \\
\end{array}$ & $\begin{array}{l}200 \text { meters away from } \\
\text { Xueze Road Station of MRT } \\
\text { Line } 2 \text {, and near } 5 \text { bus lines } \\
\text { passing by }\end{array}$ & $\begin{array}{l}150 \text { meters away from Xinjiekou } \\
\text { Metro Station of MRT } 1 \text { and 2; the } \\
\text { nearest bus stop has } 3 \text { bus lines } \\
\text { passing by }\end{array}$ & $\begin{array}{l}\text { Near the construction of } \\
\text { Hongyang Plaza Station of } \\
\text { Metro Line S8; } 2 \text { bus lines } \\
\text { passing by }\end{array}$ \\
\hline & $\begin{array}{l}\text { proximity to a } \\
\text { street corner } \\
\left(C_{2}\right)\end{array}$ & $\begin{array}{l}250 \text { meters away from the } \\
\text { intersection of Xueze Road } \\
\text { and Xianlin Avenue }\end{array}$ & $\begin{array}{l}50 \text { meters away from the intersection } \\
\text { of Shigu Road and Rich Road }\end{array}$ & $\begin{array}{l}50 \text { meters from the entrance } \\
\text { of B1 in shopping mall }\end{array}$ \\
\hline & $\begin{array}{l}\text { road width } \\
\left(C_{3}\right)\end{array}$ & $\begin{array}{l}\text { The shop is in the food } \\
\text { court, so the road is only } \\
6 \text { meters wide and only } \\
\text { pedestrians can pass }\end{array}$ & $\begin{array}{l}\text { The shop faces Shigu Road, which is } \\
\text { about } 18 \text { meters wide and can be used } \\
\text { by vehicles and pedestrians. }\end{array}$ & $\begin{array}{l}\text { The shop is not facing } \\
\text { the main arterial roads of } \\
\text { the mall and can only be } \\
\text { accessed by pedestrians }\end{array}$ \\
\hline \multirow[t]{3}{*}{$\begin{array}{l}\text { Site traits } \\
\left(D_{2}\right)\end{array}$} & $\begin{array}{l}\text { proximity } \\
\text { to public } \\
\text { facilities }\left(C_{4}\right)\end{array}$ & $\begin{array}{l}\text { Located nearby and can } \\
\text { deliver via the food delivery } \\
\text { system, including (1) } \\
\text { Government agency: the } \\
\text { Xianlin Office of the Qixia } \\
\text { District Government }\end{array}$ & $\begin{array}{l}\text { Located nearby and can deliver via the } \\
\text { food delivery system, including (1) } \\
\text { Popular tourist attractions: Xuanwu } \\
\text { Lake, Chaotian Palace, Presidential } \\
\text { Palace, Confucius Temple Scenic } \\
\text { Area, Jiangsu Provincial Art Museum, } \\
\text { Nanjing Library, Nanjing Museum, } \\
\text { Nanjing Geological Museum, Nanjing } \\
\text { Folk Customs Museum (Ganxi } \\
\text { House), Pilu Temple, Jinling Carvings, } \\
\text { Zijin Grand Theater; (2) Large parks: } \\
\text { Bailuzhou Park, Xianmen Site Park } \\
\text { and Dongshuiguan Site Park; (3) } \\
\text { Sports Center: Wutaishan Sports } \\
\text { Center, Qinhuai Sports Center, Jiangsu } \\
\text { Province }\end{array}$ & $\begin{array}{l}\text { Located nearby and can } \\
\text { delivered via the food } \\
\text { delivery system, including } \\
\text { (1) Government agency: } \\
\text { the Taishan Sub-district } \\
\text { Office; (2) Passenger Station: } \\
\text { Nanjing Long-distance Bus } \\
\text { Station, Jiangbei Passenger } \\
\text { Transport Department; (3) } \\
\text { Large-scale parks: Qiaobei } \\
\text { Riverside Ecological Park, } \\
\text { Baotashan Forest Park, } \\
\text { Liuzhou Xiaoyou Park; (4) } \\
\text { Sports Center: Pukou Culture } \\
\text { and Sports Center }\end{array}$ \\
\hline & $\begin{array}{l}\text { proximity } \\
\text { to the } \\
\text { community } \\
\left(C_{5}\right)\end{array}$ & $\begin{array}{l}\text { Located near the Yadong } \\
\text { community, the Kangqiao } \\
\text { Santa Fe community, and } \\
\text { a total of } 24 \text { residential } \\
\text { communities can be reached } \\
\text { via the food delivery system }\end{array}$ & $\begin{array}{l}\text { A total } 285 \text { small and medium } \\
\text { residential communities can be } \\
\text { reached via the food delivery system }\end{array}$ & $\begin{array}{l}\text { A total } 64 \text { residential } \\
\text { communities can be reached } \\
\text { via the food delivery } \\
\text { system, and includes larger } \\
\text { communities (such as } \\
19 \text { blocks in the Venice } \\
\text { communities and } 16 \text { blocks } \\
\text { in the Huaning Tianrun } \\
\text { Ccommunities }\end{array}$ \\
\hline & $\begin{array}{l}\text { proximity to } \\
\text { commercial } \\
\text { areas }\left(C_{6}\right)\end{array}$ & $\begin{array}{l}\text { A total of } 11 \text { shopping } \\
\text { malls, commercial offices } \\
\text { and industrial zones - } \\
\text { including Rand Information } \\
\text { Industry Park, Suning } \\
\text { Headquarters - can be } \\
\text { reached via the food } \\
\text { delivery system }\end{array}$ & $\begin{array}{l}\text { A total of } 128 \text { shopping malls, } \\
\text { commercial offices and industrial } \\
\text { zones - including Deji Mall, Ocean } \\
\text { Department Store, Central Mall and } \\
\text { Golden Eagle Department Store - } \\
\text { can be reached via the food delivery } \\
\text { system }\end{array}$ & $\begin{array}{l}\text { A total of } 15 \text { Shopping malls, } \\
\text { commercial offices and } \\
\text { industrial zones - including } \\
\text { Xiaoliu Industrial Zone in } \\
\text { Nanjing High-tech Zone, } \\
\text { Nanjing Railway Logistics } \\
\text { Base of China Railway, } \\
\text { Baotashan Creative Industry } \\
\text { Park - can be reached via the } \\
\text { food delivery system }\end{array}$ \\
\hline
\end{tabular}


End of Table 2

\begin{tabular}{|c|c|c|c|c|}
\hline Dimension & Criteria & Alternative A & Alternative B & Alternative C \\
\hline \multirow[t]{2}{*}{$\begin{array}{l}\text { Site traits } \\
\left(D_{2}\right)\end{array}$} & $\begin{array}{l}\text { proximity to } \\
\text { schools }\left(C_{7}\right)\end{array}$ & $\begin{array}{l}\text { More than } 10 \text { universities } \\
\text { and colleges, and more than } \\
10 \text { primary and secondary } \\
\text { schools }\end{array}$ & $\begin{array}{l}10 \text { universities and colleges, and } \\
\text { more than } 30 \text { primary and secondary } \\
\text { schools are located nearby }\end{array}$ & $\begin{array}{l}2 \text { colleges and } 8 \text { primary and } \\
\text { secondary schools are nearby }\end{array}$ \\
\hline & $\begin{array}{l}\text { agglomeration } \\
\text { effect }\left(C_{8}\right)\end{array}$ & $\begin{array}{l}\text { There are } 19 \text { BTSs } \\
\text { within a } 10 \text {-minute walk } \\
\text { (approximately } 600 \text { meters) } \\
\text { of this area, and } 40 \text { BTSs } \\
\text { within the delivery range for } \\
\text { food delivery systems }\end{array}$ & $\begin{array}{l}\text { There are } 51 \text { BTSs within a } 10 \text {-minute } \\
\text { walk, and there are } 424 \text { BTSs within } \\
\text { the delivery range for food delivery } \\
\text { systems }\end{array}$ & $\begin{array}{l}\text { There are } 17 \text { BTSs within } \\
\text { a } 10 \text {-minute walk, and } \\
\text { there are } 53 \text { BTSs within } \\
\text { the delivery range for food } \\
\text { delivery systems }\end{array}$ \\
\hline \multirow[t]{5}{*}{$\begin{array}{l}\text { Shop traits } \\
\left(D_{3}\right)\end{array}$} & $\begin{array}{l}\text { types of shop } \\
\left(C_{9}\right)\end{array}$ & $\begin{array}{l}\text { Street shop on first floor of } \\
\text { the horizontal food court }\end{array}$ & Traditional street shop & $\begin{array}{l}\text { Street store in B1 of shopping } \\
\text { mall }\end{array}$ \\
\hline & $\begin{array}{l}\text { sizes of shop } \\
\left(C_{10}\right)\end{array}$ & 20 square meters & 15 square meters & 15 square meters \\
\hline & $\operatorname{rent}\left(C_{11}\right)$ & $\begin{array}{l}\text { Monthly rent is RMB } 16,600 \\
\text { (RMB 830/square meter) }\end{array}$ & $\begin{array}{l}\text { Monthly rent is approximately RMB } \\
25,833 \text { (RMB } 1.722 \text { /square meter) }\end{array}$ & $\begin{array}{l}\text { Monthly rent is } \\
\text { approximately RMB } 10,000 \\
\text { (RMB 667/ square meter) }\end{array}$ \\
\hline & $\begin{array}{l}\text { business hours } \\
\left(C_{12}\right)\end{array}$ & $\begin{array}{l}\text { Operates from Monday to } \\
\text { Sunday between } 10 \text { am to } \\
10 \mathrm{pm}\end{array}$ & $\begin{array}{l}\text { Operates from Monday to Sunday } \\
\text { between } 10 \text { am to } 10 \mathrm{pm}\end{array}$ & $\begin{array}{l}\text { Operates from Monday to } \\
\text { Sunday between } 10 \text { am and } \\
10 \mathrm{pm}\end{array}$ \\
\hline & visibility $\left(C_{13}\right)$ & $\begin{array}{l}\text { Because it is not on the } \\
\text { main road, it is impossible } \\
\text { to directly see the shop sign }\end{array}$ & $\begin{array}{l}\text { It is located on Shigu Road, the shop } \\
\text { sign can be viewed directly }\end{array}$ & $\begin{array}{l}\text { It is not at the core of } \\
\text { department store, its store } \\
\text { sign can only be seen at the } \\
\text { entrance }\end{array}$ \\
\hline
\end{tabular}

\subsection{The modelling procedure for the hybrid MADM model}

A number of studies have explored location determinants of various food outlets via various MADM models or statistical analyses. As a classic methodology used in decision-making (dos Santos et al., 2019), AHP is the most commonly used approach in location selection (Tzeng et al., 2002; Özcan et al., 2011; Subramanian \& Ramanathan, 2012; Ho et al., 2013; Dehe \& Bamfor, 2015; Zhuang et al., 2017, 2018a, 2018b, 2019; Yıldız \& Tüysüz, 2019); however, unrealistic assumptions concerning the independent relationship among the concerning factors presents a drawback (Liu et al., 2018a; Shen \& Tzeng, 2018; Chen et al., 2019; Lin et al., 2021). Although the Analytic Network Process (ANP) method tries to explore the mutual influence relationship (Tolga et al., 2013; Neumüller et al., 2015), it also lacks a strong support for interactions relationship (Gölcük \& Baykasoĝlua, 2016). In order to make the location determinants in choosing a site for a BTS more realistic and persuasive, this study introduces a hybrid MADM model that considers the interaction between the identified factors.

Although existing research has explored location selection for various facilities based on the relationship between concerning factors (Kuo, 2011; Liu et al., 2018a; Shahi et al., 2018; Trivedi, 2018; Wu et al., 2019), this model has not been applied in regard to food retail stores or restaurants. Specifically, four steps are followed for the MADM procedure used in this study. The conceptual framework for modeling is shown in Figure 3 and descriptions of each procedure are explained simply in the following sub-sections.

\section{Questionnaire-based data collection}

This study aimed to explore the determinants regarding the choice of a location for a BTS considering the relationships among dimensions/criteria. The applied MADM model makes use of evaluation via experts' opinions and can be effectively utilized without a large number of samples. Seven experts were surveyed, via either email or fax, between July and August, 2019. The number of experts called upon is equal to that used by Liu et al. (2018b).

The information related to the seven experts are indicated in Table 3. The experts were divided into academic and industrial sectors, of which there were three in the former and four in the latter. The three experts in the academic sector all have doctoral degrees, and are currently associate or assistant professors at their respective universities. They all have working experience of between three and five years and are involved in different academic concerns - such as human geography, land management, and business management. In terms of the industry experts, half of the interviewees have a master's degree and currently hold management positions in the catering and BTS industries. The range of working experience for the industry interviewees spans three to 15 years.

The questionnaire was designed in Chinese, and divided into three parts. The first part was designed to collect the experts' basic information. The second part included a five-point Likert scale (no impact $\leftarrow 0,1,2,3,4 \rightarrow$ very high impact) for evaluating the impact of the relationship 


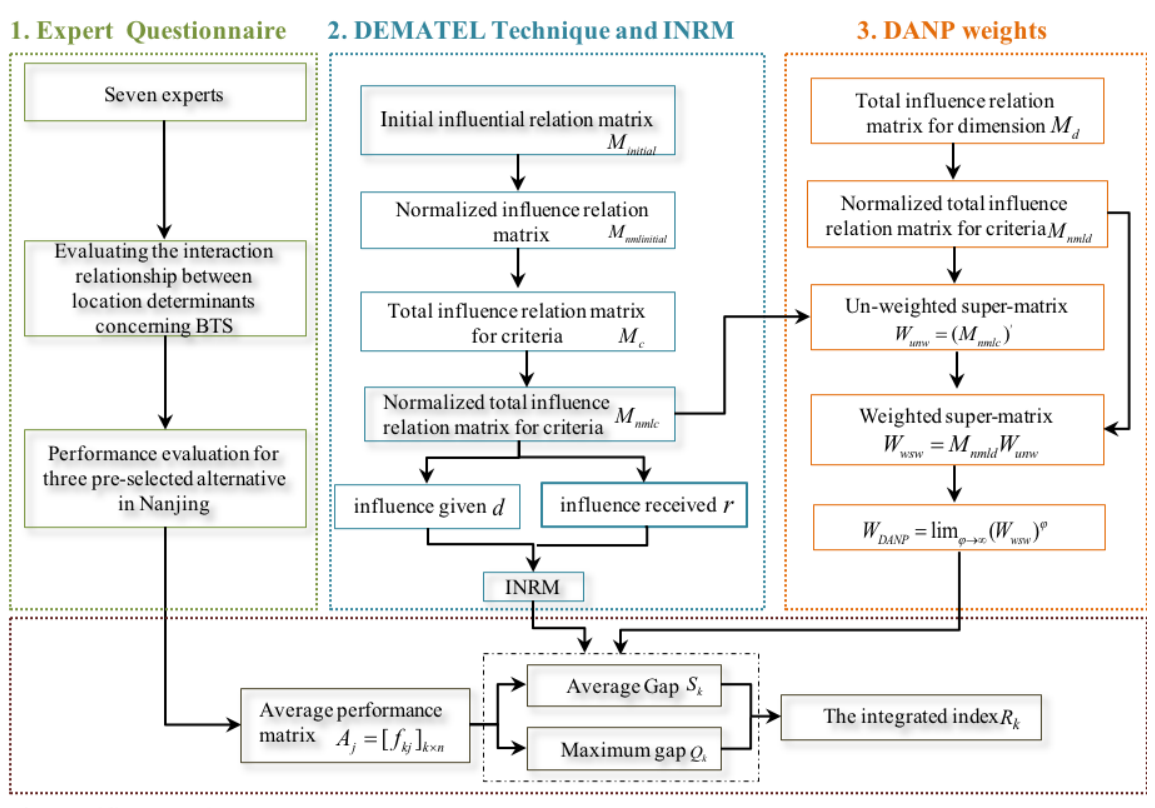

4. Modified VIKOR

Figure 3. MADM procedures for exploring the location determinants of BTSs

between two certain factors. The third part included a 10 -point Likert scale (very unsatisfied $\leftarrow 1,2, \ldots, 9,10 \rightarrow$ very satisfied) to evaluate the performance of each criteria for the three pre-selected alternatives (as indicated in Table 2). Full questionnaire form have been provided in Appendix A.

\section{Exploring the relationship between criteria concerning the choice in location of BTSs as based on DEMATEL technique and an INRM}

Between 1972 and 1976, the Science and Human Affairs Program of the Battelle Memorial Institute of Geneva (United Nations) developed the DEMATEL technique for clarifying and solving complex problems for global issues (Gabus \& Fontela, 1972, 1973). More and more studies have come to recognize the presence of complex interactions throughout the real world, in addition to simple linear relationships (Tzeng \& Shen, 2017; Lin et al., 2021). Hence, DEMATEL has been highlighted in a variety of decision-making issues, and Dr. Tzeng, G. H. from Taiwan has further deepened and hybrid- ized the approach with other methods so as to form a more forward-looking, and solid, hybrid MADM model for use across various decision-making fields (Lin, 2019). With the DEMATEL technique, constructing an influential network relationship map (INRM) to identify the interactions among the criteria under evaluation is an important step. INRM concerns the extent to which a certain criterion affects, and is affected by, other criteria; this is beneficial in identifying which criteria are key in guiding decision-makers in resource allocation tasks. In this study, DEMATEL and INRM are utilized to identify the relationship and their key kore between criteria concerning location determinants.

The modeling process for the DEMATEL technique and the INRM is as follows (please refer to the more detailed formulas provided in Appendix B.1): (1) constructing the initial influential relation matrix $M_{\text {initial }}$ according to the opinions provided by the experts interviewed; (2) obtaining the normalized influence relationship matrix $M_{n \text { mlinitial }}$; (3) calculating the total relationship influence matrix for criteria $M_{\mathcal{c}}$; and (4) finally, the sum vector of the row $d$ (representing the sum based on direct or indirect influence had

Table 3. Information of interviewed seven experts

\begin{tabular}{|l|l|l|c|l|c|}
\hline \multicolumn{1}{|c|}{ Sector } & Number & \multicolumn{1}{|c|}{ Department } & Degree & \multicolumn{1}{c|}{ Position } & Working years \\
\hline \multirow{4}{*}{ Academic } & Expert 1 & Human geography & Ph.D. & Associate professor & 5 \\
\cline { 2 - 6 } & Expert 2 & Land management & Ph.D. & Associate professor & 4 \\
\cline { 2 - 6 } & Expert 3 & Business management & Ph.D. & Assistant professor & 3 \\
\hline \multirow{4}{*}{ Industry } & Expert 4 & Catering & Bachelor & Chief Operating Officer & 15 \\
\cline { 2 - 6 } & Expert 5 & BTS industry & Master & Regional manager & 3 \\
\cline { 2 - 6 } & Expert 6 & BTS industry & Master & Manager & 7 \\
\cline { 2 - 6 } & Expert 7 & BTS industry & Bachelor & Manager & 8 \\
\hline
\end{tabular}


upon the other criteria, i.e. influence given) and the sum vector of the column $r$ (representing the sum concerning how directly or indirectly the criterion is affected by other criteria, i.e. influence received) are indicated in Table 4. Following this, the INRM is established based on $(d+r)$ (horizontal axis) and $(d-r)$ (vertical axis).

In this regard, some attention should be placed upon: (1) the dimension/criteria with bigger $(d+r)$, indicating a stronger total influence, and vice versa; (2) the dimension/ criteria with bigger $(d-r)$, indicating a stronger ability to influence other. Among these, criteria with a greater positive $(d-r)$ is deemed as being more important because it belongs to the "cause" that affects others (the larger the positive value, the greater the ability to influence others). Conversely, negative values for $(d-r)$ indicate that the criterion is affected by other criteria - the larger the negative value, the greater the impact had by others.

\section{Calculating the influential weights of criteria of BTS location determinants based on DANP}

Although traditional ANP methodology (Saaty, 1996) addresses some unreasonable conditions found in the use of AHP - that is, by relaxing the assumption of relationships found between criteria (Kheybari et al., 2020) - it is still being questioned. Due to users of ANP briefly assuming that the diagonal matrix is equal to the zero matrix and the weighted super-matrix (as obtained by using equal weights - Tzeng \& Shen, 2017; Peng \& Tzeng, 2019; Lin et al., 2021), ANP methodology is facing a challenge in its ability to compare internal and external dependencies in pairs (Gölcük \& Baykasoĝlua, 2016). The DANP, combined with DEMATEL and ANP, can better improve upon this shortage (Ou Yang et al., 2013) and the development prospects in the field of MADM (Gölcük \& Baykasoĝlua, 2016). This revised method introduces the influence relation matrix for criteria and for dimensions based on DEMATEL into the matrix of the traditional ANP. Compared to ANP, DANP has more advantages than traditional ANP (Liu et al., 2018a, 2018b). In this study, the DANP's weighting is utilized for key identification on location determinants and an evaluation foundation for pre-selected location concerning BTSs.

The modeling process for DANP is as follows (please refer to the more-detailed formulas provided in Appendix B.2): (1) $M_{\mathcal{c}}$, as derived via DEMATEL, is normalized to obtain the normalized total influence relationship matrix for criteria $M_{n m l c}$; and the $M_{d}$ obtained (in a similar way to $M_{c}$ ) is normalized to produce a total influence relation matrix for dimension $M_{n m l d}$; (2) $M_{n m l c}$ will be transposed to obtain the un-weighted super-matrix $W_{\text {unw }}=\left(M_{n m l c}\right)^{\prime}-M_{n m l d}$ is then also introduced to $W_{\text {unw }}=\left(M_{n m l c}\right)^{\prime}$ to obtain the weighted super-matrix $W_{w s w}=M_{n m l d} W_{u n w}$; (3) after $W_{w s w}$ is multiplied by itself a hundred times (that is $\left.W_{D A N P}=\lim _{\varphi \rightarrow \infty}\left(W_{w s w}\right)^{\varphi}\right)$, the weighted super-matrix converges to become a stable super-matrix, eventually forming a local weight applicable to the DANP. The global weights of each DANP criteria are calculated based on their local weights, multiply by the local weights of its own dimensions.

\section{Evaluating the performance and GAP of three alternatives in Nanjing based on modified VIKOR methodology}

The modifed Vlse Kriterijumska Optimizacija I Kompromisno Resenje (VIKOR) method was utilized to evaluate the performance and gap for the three pre-selected cases used in this study. The modified VIKOR was presented by Opricovic and Tzeng $(2004,2007)$ and carries more advantages than the traditional VIKOR methodology. Traditional VIKOR methodology usually utilizes the class distance function (i.e. zero is equal to a negative ideal solution, and one is equal to a positive ideal solution) for ranking and selecting alternatives. This causes one to "pick the best apple among a barrel of rotten apples." Liu et al. (2018b) indicated that this is because the selection of alternatives must contain at least two alternatives, and that in the performance of GAP at least one of the alternatives is zero (meaning no improvement is required). In other hands, a GAP ratio cannot be obtained because the denominator of the formula is zero at this time and these criteria must be eliminated when the performance score of the criteria is equal (in context of evaluating multiple alternatives). Importantly, the improvement strategies cannot be obtained. The modified VIKOR methodology utilizes the "ideal values" as the aspiration level (i.e. equal to ten points) and "worst value" as benchmark (i.e. equal to zero points), avoiding traditional questions while also presenting the improvement strategies for achieving the "aspiration level" via combing with INRM via DEMATEL.

The modeling process for modified VIKOR methodology is described as follows (please refer to Appendix B.3 for a more detailed explanation): (1) establishing the average performance score based on the feedback provided by experts and scholars $A_{j}=\left[f_{k j}\right]_{k \times n} ;(2)$ combining the local weighting of DANP, determining the optimal GAP through the average GAP (with aspiration level $S_{k}$ ) and the maximum GAP (with aspiration level $Q_{k}$ ) for the three pre-selected alternatives form the optimal integration in$\operatorname{dex}\left(R_{k}\right)$.

\section{Empirical findings}

\subsection{Calculated results of DEMATEL and DANP}

In terms of DEMATEL, calculated result for the initial influential relation matrix $M_{\text {initial }}$ are presented in Table 4; the normalized influence relation matrix $M_{\text {nmlinitial }}$ is presented in Table 5; the total influence relationship matrix for criteria $M_{c}$ is presented in Table 6.

In terms of DANP, the un-weighted super-matrix $W_{u n w}=\left(M_{n m l c}\right)^{\prime}$ is indicated in Table 7, and the weighted super-matrix $W_{w s w}=M_{n m l d} W_{u n w}$ is indicated in Table 8. 
Table 4. Initial influential relation matrix $M_{\text {initial }}$

\begin{tabular}{|l|c|c|c|c|c|c|c|c|c|c|c|c|c|}
\hline & $C_{1}$ & $C_{2}$ & $C_{3}$ & $C_{4}$ & $C_{5}$ & $C_{6}$ & $C_{7}$ & $C_{8}$ & $C_{9}$ & $C_{10}$ & $C_{11}$ & $C_{12}$ & $C_{13}$ \\
\hline$C_{1}$ & 0.000 & 2.571 & 3.000 & 2.571 & 2.429 & 2.000 & 1.714 & 1.714 & 2.143 & 2.429 & 2.857 & 2.571 & 2.714 \\
\hline$C_{2}$ & 1.714 & 0.000 & 4.000 & 1.429 & 2.429 & 1.857 & 1.429 & 1.429 & 1.857 & 1.571 & 2.000 & 1.714 & 1.571 \\
\hline$C_{3}$ & 2.286 & 3.000 & 0.000 & 2.000 & 2.571 & 2.429 & 1.857 & 1.714 & 2.429 & 2.000 & 2.286 & 2.000 & 3.000 \\
\hline$C_{4}$ & 1.571 & 1.429 & 2.286 & 0.000 & 2.571 & 1.429 & 0.857 & 0.857 & 1.429 & 1.857 & 2.143 & 2.000 & 2.286 \\
\hline$C_{5}$ & 2.429 & 2.000 & 3.143 & 2.714 & 0.000 & 2.143 & 1.857 & 1.714 & 2.143 & 1.857 & 2.429 & 2.000 & 2.714 \\
\hline$C_{6}$ & 2.286 & 2.429 & 3.429 & 2.714 & 3.286 & 0.000 & 2.429 & 2.286 & 2.714 & 2.571 & 2.714 & 2.429 & 2.857 \\
\hline$C_{7}$ & 2.429 & 2.714 & 3.143 & 2.286 & 3.143 & 2.857 & 0.000 & 2.429 & 2.000 & 1.429 & 1.571 & 1.429 & 1.571 \\
\hline$C_{8}$ & 2.143 & 2.143 & 2.714 & 1.429 & 2.857 & 2.429 & 2.000 & 0.000 & 2.000 & 1.714 & 1.857 & 1.714 & 1.857 \\
\hline$C_{9}$ & 1.571 & 1.714 & 2.857 & 2.143 & 2.857 & 2.143 & 1.571 & 1.571 & 0.000 & 1.429 & 1.714 & 1.571 & 1.857 \\
\hline$C_{10}$ & 2.571 & 2.143 & 2.714 & 3.286 & 2.857 & 1.571 & 1.429 & 1.571 & 2.286 & 0.000 & 1.429 & 1.286 & 2.143 \\
\hline$C_{11}$ & 2.857 & 2.714 & 3.714 & 3.571 & 3.000 & 2.000 & 1.571 & 1.714 & 2.143 & 1.286 & 0.000 & 1.429 & 3.000 \\
\hline$C_{12}$ & 2.000 & 2.286 & 3.143 & 3.000 & 2.571 & 1.571 & 1.286 & 1.429 & 1.571 & 1.286 & 1.571 & 0.000 & 2.143 \\
\hline$C_{13}$ & 2.714 & 2.143 & 3.429 & 2.714 & 3.286 & 2.429 & 1.857 & 1.571 & 1.429 & 1.429 & 2.429 & 1.714 & 0.000 \\
\hline
\end{tabular}

Notes: $C_{1}=$ proximity to public transportation system; $C_{2}=$ proximity to a street corner; $C_{3}=$ road width; $C_{4}=$ proximity to public facilities; $C_{5}=$ proximity to the community; $C_{6}=$ proximity to commercial area; $C_{7}=$ proximity to school; $C_{8}=$ agglomeration effect; $C_{9}=$ types of shop; $C_{10}=$ sizes of shop; $C_{11}=$ rent; $C_{12}=$ business hours; $C_{13}=$ visibility.

Table 5. Normalized influence relation matrix $M_{\text {nmlinitial }}$

\begin{tabular}{|l|c|c|c|c|c|c|c|c|c|c|c|c|c|}
\hline & $C_{1}$ & $C_{2}$ & $C_{3}$ & $C_{4}$ & $C_{5}$ & $C_{6}$ & $C_{7}$ & $C_{8}$ & $C_{9}$ & $C_{10}$ & $C_{11}$ & $C_{12}$ & $C_{13}$ \\
\hline$C_{1}$ & 0.000 & 0.068 & 0.080 & 0.068 & 0.065 & 0.053 & 0.046 & 0.046 & 0.057 & 0.065 & 0.076 & 0.068 & 0.072 \\
\hline$C_{2}$ & 0.046 & 0.000 & 0.106 & 0.038 & 0.065 & 0.049 & 0.038 & 0.038 & 0.049 & 0.042 & 0.053 & 0.046 & 0.042 \\
\hline$C_{3}$ & 0.061 & 0.080 & 0.000 & 0.053 & 0.068 & 0.065 & 0.049 & 0.046 & 0.065 & 0.053 & 0.061 & 0.053 & 0.080 \\
\hline$C_{4}$ & 0.042 & 0.038 & 0.061 & 0.000 & 0.068 & 0.038 & 0.023 & 0.023 & 0.038 & 0.049 & 0.057 & 0.053 & 0.061 \\
\hline$C_{5}$ & 0.065 & 0.053 & 0.084 & 0.072 & 0.000 & 0.057 & 0.049 & 0.046 & 0.057 & 0.049 & 0.065 & 0.053 & 0.072 \\
\hline$C_{6}$ & 0.061 & 0.065 & 0.091 & 0.072 & 0.087 & 0.000 & 0.065 & 0.061 & 0.072 & 0.068 & 0.072 & 0.065 & 0.076 \\
\hline$C_{7}$ & 0.065 & 0.072 & 0.084 & 0.061 & 0.084 & 0.076 & 0.000 & 0.065 & 0.053 & 0.038 & 0.042 & 0.038 & 0.042 \\
\hline$C_{8}$ & 0.057 & 0.057 & 0.072 & 0.038 & 0.076 & 0.065 & 0.053 & 0.000 & 0.053 & 0.046 & 0.049 & 0.046 & 0.049 \\
\hline$C_{9}$ & 0.042 & 0.046 & 0.076 & 0.057 & 0.076 & 0.057 & 0.042 & 0.042 & 0.000 & 0.038 & 0.046 & 0.042 & 0.049 \\
\hline$C_{10}$ & 0.068 & 0.057 & 0.072 & 0.087 & 0.076 & 0.042 & 0.038 & 0.042 & 0.061 & 0.000 & 0.038 & 0.034 & 0.057 \\
\hline$C_{11}$ & 0.076 & 0.072 & 0.099 & 0.095 & 0.080 & 0.053 & 0.042 & 0.046 & 0.057 & 0.034 & 0.000 & 0.038 & 0.080 \\
\hline$C_{12}$ & 0.053 & 0.061 & 0.084 & 0.080 & 0.068 & 0.042 & 0.034 & 0.038 & 0.042 & 0.034 & 0.042 & 0.000 & 0.057 \\
\hline$C_{13}$ & 0.072 & 0.057 & 0.091 & 0.072 & 0.087 & 0.065 & 0.049 & 0.042 & 0.038 & 0.038 & 0.065 & 0.046 & 0.000 \\
\hline
\end{tabular}

Notes: $C_{1}=$ proximity to public transportation system; $C_{2}=$ proximity to a street corner; $C_{3}=$ road width; $C_{4}=$ proximity to public facilities; $C_{5}=$ proximity to the community; $C_{6}=$ proximity to commercial area; $C_{7}=$ proximity to school; $C_{8}=$ agglomeration effect; $C_{9}=$ types of shop; $C_{10}=$ sizes of shop; $C_{11}=$ rent; $C_{12}=$ business hours; $C_{13}=$ visibility.

Table 6. Total influence relationship matrix for criteria $M_{c}$

\begin{tabular}{|l|c|c|c|c|c|c|c|c|c|c|c|c|c|}
\hline & $C_{1}$ & $C_{2}$ & $C_{3}$ & $C_{4}$ & $C_{5}$ & $C_{6}$ & $C_{7}$ & $C_{8}$ & $C_{9}$ & $C_{10}$ & $C_{11}$ & $C_{12}$ & $C_{13}$ \\
\hline$C_{1}$ & 0.139 & 0.207 & 0.267 & 0.219 & 0.234 & 0.181 & 0.149 & 0.148 & 0.181 & 0.172 & 0.204 & 0.181 & 0.215 \\
\hline$C_{2}$ & 0.157 & 0.118 & 0.255 & 0.163 & 0.202 & 0.154 & 0.123 & 0.123 & 0.152 & 0.131 & 0.160 & 0.139 & 0.162 \\
\hline$C_{3}$ & 0.191 & 0.212 & 0.187 & 0.200 & 0.232 & 0.187 & 0.149 & 0.145 & 0.183 & 0.158 & 0.186 & 0.163 & 0.216 \\
\hline$C_{4}$ & 0.143 & 0.142 & 0.199 & 0.115 & 0.192 & 0.132 & 0.100 & 0.100 & 0.130 & 0.129 & 0.153 & 0.137 & 0.167 \\
\hline$C_{5}$ & 0.193 & 0.186 & 0.260 & 0.215 & 0.165 & 0.178 & 0.147 & 0.143 & 0.175 & 0.153 & 0.188 & 0.162 & 0.208 \\
\hline$C_{6}$ & 0.212 & 0.220 & 0.298 & 0.240 & 0.274 & 0.146 & 0.178 & 0.174 & 0.209 & 0.188 & 0.216 & 0.191 & 0.235 \\
\hline$C_{7}$ & 0.192 & 0.203 & 0.260 & 0.203 & 0.242 & 0.195 & 0.101 & 0.161 & 0.172 & 0.144 & 0.168 & 0.148 & 0.180 \\
\hline$C_{8}$ & 0.176 & 0.180 & 0.237 & 0.173 & 0.224 & 0.176 & 0.144 & 0.093 & 0.163 & 0.142 & 0.165 & 0.147 & 0.177 \\
\hline
\end{tabular}


End of Table 6

\begin{tabular}{|l|c|c|c|c|c|c|c|c|c|c|c|c|c|}
\hline & $C_{1}$ & $C_{2}$ & $C_{3}$ & $C_{4}$ & $C_{5}$ & $C_{6}$ & $C_{7}$ & $C_{8}$ & $C_{9}$ & $C_{10}$ & $C_{11}$ & $C_{12}$ & $C_{13}$ \\
\hline$C_{9}$ & 0.153 & 0.160 & 0.227 & 0.180 & 0.212 & 0.160 & 0.126 & 0.126 & 0.104 & 0.128 & 0.153 & 0.136 & 0.168 \\
\hline$C_{10}$ & 0.186 & 0.179 & 0.236 & 0.217 & 0.223 & 0.155 & 0.129 & 0.132 & 0.169 & 0.099 & 0.155 & 0.137 & 0.184 \\
\hline$C_{11}$ & 0.211 & 0.211 & 0.285 & 0.243 & 0.249 & 0.182 & 0.146 & 0.149 & 0.182 & 0.146 & 0.136 & 0.156 & 0.224 \\
\hline$C_{12}$ & 0.166 & 0.176 & 0.238 & 0.203 & 0.208 & 0.149 & 0.121 & 0.124 & 0.146 & 0.127 & 0.152 & 0.098 & 0.177 \\
\hline$C_{13}$ & 0.201 & 0.191 & 0.268 & 0.216 & 0.246 & 0.186 & 0.148 & 0.141 & 0.159 & 0.144 & 0.190 & 0.156 & 0.142 \\
\hline
\end{tabular}

Notes: $C_{1}=$ proximity to public transportation system; $C_{2}=$ proximity to a street corner; $C_{3}=$ road width; $C_{4}=$ proximity to public facilities; $C_{5}=$ proximity to the community; $C_{6}=$ proximity to commercial area; $C_{7}=$ proximity to school; $C_{8}=$ agglomeration effect; $C_{9}=$ types of shop; $C_{10}=$ sizes of shop; $C_{11}=$ rent; $C_{12}=$ business hours; $C_{13}=$ visibility.

Table 7. Un-weighted super-matrix $W_{u n w}=\left(M_{n m l c}\right)^{\prime}$

\begin{tabular}{|c|c|c|c|c|c|c|c|c|c|c|c|c|c|}
\hline & $C_{1}$ & $C_{2}$ & $C_{3}$ & $C_{4}$ & $C_{5}$ & $C_{6}$ & $C_{7}$ & $C_{8}$ & $C_{9}$ & $C_{10}$ & $C_{11}$ & $C_{12}$ & $C_{13}$ \\
\hline$C_{1}$ & 0.130 & 0.166 & 0.187 & 0.181 & 0.189 & 0.171 & 0.175 & 0.178 & 0.164 & 0.179 & 0.186 & 0.167 & 0.279 \\
\hline$C_{2}$ & 0.194 & 0.131 & 0.208 & 0.179 & 0.183 & 0.177 & 0.185 & 0.182 & 0.172 & 0.172 & 0.176 & 0.178 & 0.170 \\
\hline$C_{3}$ & 0.250 & 0.265 & 0.183 & 0.252 & 0.255 & 0.240 & 0.236 & 0.239 & 0.244 & 0.227 & 0.238 & 0.240 & 0.008 \\
\hline$C_{4}$ & 0.206 & 0.182 & 0.196 & 0.146 & 0.211 & 0.193 & 0.184 & 0.174 & 0.193 & 0.228 & 0.203 & 0.205 & 0.192 \\
\hline$C_{5}$ & 0.220 & 0.226 & 0.227 & 0.242 & 0.162 & 0.220 & 0.220 & 0.226 & 0.228 & 0.214 & 0.208 & 0.210 & 0.220 \\
\hline$C_{6}$ & 0.378 & 0.355 & 0.388 & 0.398 & 0.380 & 0.292 & 0.427 & 0.426 & 0.389 & 0.310 & 0.332 & 0.378 & 0.391 \\
\hline$C_{7}$ & 0.311 & 0.403 & 0.310 & 0.302 & 0.314 & 0.358 & 0.220 & 0.349 & 0.306 & 0.310 & 0.307 & 0.307 & 0.352 \\
\hline$C_{8}$ & 0.311 & 0.307 & 0.302 & 0.300 & 0.306 & 0.350 & 0.352 & 0.225 & 0.305 & 0.317 & 0.322 & 0.314 & 0.297 \\
\hline$C_{9}$ & 0.190 & 0.204 & 0.202 & 0.182 & 0.197 & 0.201 & 0.212 & 0.205 & 0.151 & 0.239 & 0.216 & 0.208 & 0.201 \\
\hline$C_{10}$ & 0.180 & 0.177 & 0.174 & 0.180 & 0.173 & 0.181 & 0.177 & 0.179 & 0.186 & 0.133 & 0.174 & 0.181 & 0.202 \\
\hline$C_{11}$ & 0.214 & 0.211 & 0.206 & 0.213 & 0.212 & 0.208 & 0.207 & 0.208 & 0.222 & 0.208 & 0.171 & 0.217 & 0.240 \\
\hline$C_{12}$ & 0.190 & 0.166 & 0.180 & 0.191 & 0.183 & 0.183 & 0.183 & 0.185 & 0.197 & 0.184 & 0.184 & 0.140 & 0.198 \\
\hline$C_{13}$ & 0.226 & 0.207 & 0.238 & 0.233 & 0.235 & 0.226 & 0.222 & 0.223 & 0.244 & 0.277 & 0.285 & 0.253 & 0.251 \\
\hline
\end{tabular}

Notes: $C_{1}=$ proximity to public transportation system; $C_{2}=$ proximity to a street corner; $C_{3}=$ road width; $C_{4}=$ proximity to public facilities; $C_{5}=$ proximity to the community; $C_{6}=$ proximity to commercial area; $C_{7}=$ proximity to school; $C_{8}=$ agglomeration effect; $C_{9}=$ types of shop; $C_{10}=$ sizes of shop; $C_{11}=$ rent; $C_{12}=$ business hours; $C_{13}=$ visibility.

Table 8. Weighted super-matrix $W_{w s w}=M_{n m l d} W_{\text {unw }}$

\begin{tabular}{|l|c|c|c|c|c|c|c|c|c|c|c|c|c|}
\hline & $C_{1}$ & $C_{2}$ & $C_{3}$ & $C_{4}$ & $C_{5}$ & $C_{6}$ & $C_{7}$ & $C_{8}$ & $C_{9}$ & $C_{10}$ & $C_{11}$ & $C_{12}$ & $C_{13}$ \\
\hline$C_{1}$ & 0.043 & 0.071 & 0.081 & 0.071 & 0.072 & 0.077 & 0.079 & 0.081 & 0.077 & 0.080 & 0.087 & 0.079 & 0.131 \\
\hline$C_{2}$ & 0.083 & 0.056 & 0.080 & 0.077 & 0.079 & 0.080 & 0.084 & 0.083 & 0.081 & 0.081 & 0.083 & 0.084 & 0.080 \\
\hline$C_{3}$ & 0.102 & 0.105 & 0.078 & 0.098 & 0.110 & 0.109 & 0.107 & 0.109 & 0.115 & 0.107 & 0.112 & 0.113 & 0.004 \\
\hline$C_{4}$ & 0.088 & 0.078 & 0.084 & 0.063 & 0.081 & 0.087 & 0.084 & 0.079 & 0.091 & 0.108 & 0.095 & 0.096 & 0.090 \\
\hline$C_{5}$ & 0.090 & 0.084 & 0.097 & 0.100 & 0.070 & 0.100 & 0.100 & 0.103 & 0.107 & 0.093 & 0.098 & 0.099 & 0.103 \\
\hline$C_{6}$ & 0.073 & 0.069 & 0.075 & 0.077 & 0.074 & 0.054 & 0.080 & 0.079 & 0.075 & 0.060 & 0.064 & 0.073 & 0.081 \\
\hline$C_{7}$ & 0.050 & 0.078 & 0.051 & 0.053 & 0.061 & 0.067 & 0.041 & 0.065 & 0.059 & 0.060 & 0.059 & 0.059 & 0.068 \\
\hline$C_{8}$ & 0.107 & 0.116 & 0.104 & 0.113 & 0.105 & 0.065 & 0.066 & 0.042 & 0.059 & 0.061 & 0.062 & 0.061 & 0.057 \\
\hline$C_{9}$ & 0.072 & 0.077 & 0.076 & 0.060 & 0.064 & 0.072 & 0.076 & 0.074 & 0.051 & 0.080 & 0.070 & 0.070 & 0.075 \\
\hline$C_{10}$ & 0.058 & 0.067 & 0.056 & 0.065 & 0.065 & 0.065 & 0.064 & 0.064 & 0.062 & 0.045 & 0.058 & 0.061 & 0.068 \\
\hline$C_{11}$ & 0.081 & 0.070 & 0.070 & 0.075 & 0.070 & 0.075 & 0.074 & 0.075 & 0.075 & 0.070 & 0.054 & 0.073 & 0.085 \\
\hline$C_{12}$ & 0.072 & 0.061 & 0.068 & 0.067 & 0.062 & 0.066 & 0.066 & 0.067 & 0.066 & 0.062 & 0.062 & 0.047 & 0.071 \\
\hline$C_{13}$ & 0.080 & 0.068 & 0.080 & 0.081 & 0.089 & 0.081 & 0.080 & 0.080 & 0.082 & 0.093 & 0.094 & 0.085 & 0.084 \\
\hline
\end{tabular}

Notes: $C_{1}=$ proximity to public transportation system; $C_{2}=$ proximity to a street corner; $C_{3}=$ road width; $C_{4}=$ proximity to public facilities; $C_{5}=$ proximity to the community; $C_{6}=$ proximity to commercial area; $C_{7}=$ proximity to school; $C_{8}=$ agglomeration effect; $C_{9}=$ types of shop; $C_{10}=$ sizes of shop; $C_{11}=$ rent; $C_{12}=$ business hours; $C_{13}=$ visibility. 


\subsection{Identification of location determinants of BTSs based on DEMATEL and DANP methodology}

The empirical results of DEMATEL and DANP are indicated in Table 9. The results of importance, based on $(d+r)$, indicate that Shop traits $\left(D_{3}\right)(24.569)$ ranks higher than both Site traits $\left(D_{2}\right)(21.843)$ and Traffic traits $\left(D_{1}\right)$ (13.049). Based on the influence received $(d-r)$, as per DEMATEL and INRM (see Figure 4$)$, Traffic traits $\left(D_{1}\right)$ (1.647) and Site traits $\left(D_{2}\right)(0.608)$ produce positive values (indicating cause), whereas Shop traits $\left(D_{3}\right)(-2.255)$ produces a negative value (indicating of effect).

These calculations are intended as a means to analyse the relationship between criteria. In according with $(d-$ $r$ ), five criteria present with higher-than-average threshold values of 4.574 (i.e. the average value of all criteria), including: rent $\left(C_{11}\right)(5.626)$, visibility $\left(C_{13}\right)(5.277)$, proximity to public transportation system $\left(C_{1}\right)$ (4.962), types of shop $\left(C_{9}\right)(4.818)$, and proximity to commercial area $\left(C_{6}\right)$ (4.746); meanwhile, seven criteria fall below the threshold. Analyzing the position of criteria via $(d-r)$ indicates that proximity to a street corner $\left(C_{2}\right)(0.607)$, proximity to public transportation systems $\left(C_{1}\right)(0.602)$, road width $\left(C_{3}\right)(0.438)$, proximity to communities $\left(C_{5}\right)(0.340)$, proximity to commercial areas $\left(C_{6}\right)(0.294)$, types of shop $\left(C_{9}\right)$ $(0.176)$, and proximity to schools $\left(C_{7}\right)(0.135)$ are considered as "causes" which impact other factors (given their positive values), while six criteria belong to the category of "effect" which are impacted by other factors (due to their negative value).
According to the local weighting of DANP in Table 9, the most important dimension is that of Shop traits $\left(D_{3}\right)$ (0.434), followed by Site traits $\left(D_{2}\right)(0.351)$, and, lastly, Traffic traits $\left(D_{1}\right)(1.647)$. The global weights reveal that the first three major weights are present via rent $\left(C_{11}\right)$ (0.096), visibility $\left(C_{13}\right)(0.095)$, and business hours $\left(C_{12}\right)$ (0.085). The three factors carrying the lowest weights are proximity to schools $\left(C_{7}\right)(0.064)$, proximity to communities $\left(C_{5}\right)(0.061)$, and proximity to a street corner $\left(C_{2}\right)$.

By combining the results obtained via DEMATEL and ANP methodology, one can observe that Traffic traits $\left(D_{1}\right)$ and Site traits $\left(D_{2}\right)$ play key roles in decisions made around the choice of a BTS' location and must, therefore, be considered first - this is particularly true for Traffic traits $\left(D_{1}\right)$, which presents with the highest $(d-r)$ value. Once these dimensions, which fall under the category of "cause," are improved upon, Shop traits $\left(D_{3}\right)$ (which belong to the "effect" grouping) have also be improved. In terms of criteria, although rent $\left(C_{11}\right)$, visibility $\left(C_{13}\right)$, business hours $\left(C_{12}\right)$, and agglomeration effect $\left(C_{8}\right)$ present with higher $(d+r)$ values (as per DEMATEL methodology) and global weights (as per DANP methodology), these criteria should not be the first considerations given their negative $(d-r)$ values. Conversely, criteria which present with positive $(d-r)$ values should be more critical determinants of BTSs' choices for a location. These criteria include, in descending order, proximity to a street corner $\left(C_{2}\right)$, proximity to public transportation systems $\left(C_{1}\right)$, road width $\left(C_{3}\right)$, proximity to communities $\left(C_{5}\right)$, proximity to commercial areas $\left(C_{6}\right)$, types of shop $\left(C_{9}\right)$, and proximity to schools $\left(C_{7}\right)$.

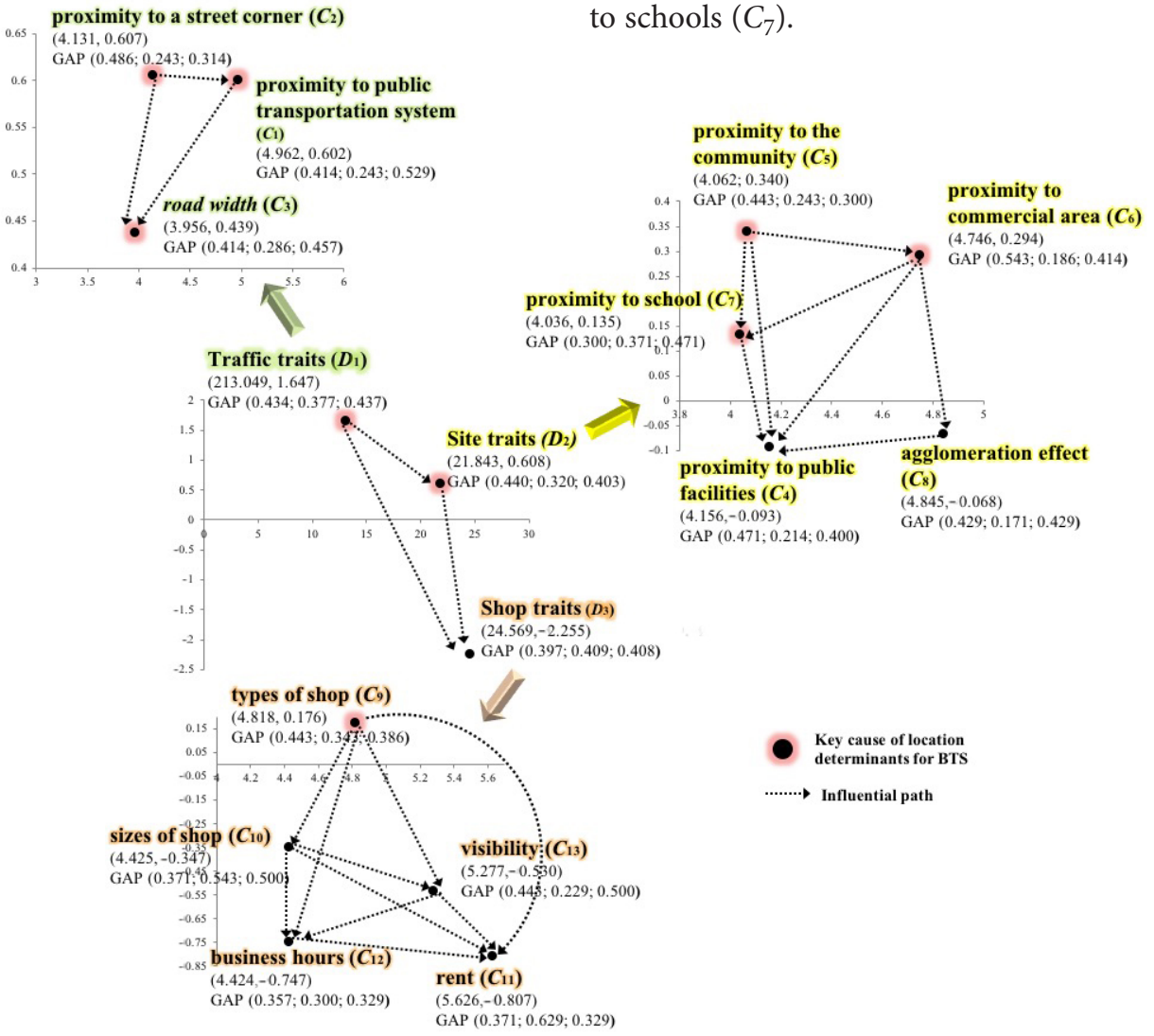

Figure 4. INRM to determine relationships between location determinants of BTSs 
Table 9. The result of criteria calculated via DEMATEL and DANP

\begin{tabular}{|l|c|c|c|c|c|c|}
\hline & $d$ & $r$ & $(d+r)$ & $(d-r)$ & $\begin{array}{c}\text { Local } \\
\text { weight }\end{array}$ & $\begin{array}{c}\text { Global weight } \\
(\text { Ranking) }\end{array}$ \\
\hline Traffic traits $\left(D_{1}\right)$ & 7.348 & 5.701 & 13.049 & 1.647 & 0.216 & \\
\hline proximity to public transportation system $\left(C_{1}\right)$ & 2.782 & 2.180 & 4.962 & 0.602 & 0.352 & $0.076(8)$ \\
\hline proximity to a street corner $\left(C_{2}\right)$ & 2.369 & 1.762 & 4.131 & 0.607 & 0.275 & $0.059(13)$ \\
\hline road width $\left(C_{3}\right)$ & 2.197 & 1.759 & 3.956 & 0.438 & 0.372 & $0.080(5)$ \\
\hline Site traits $\left(D_{2}\right)$ & 11.225 & 10.617 & 21.843 & 0.608 & 0.351 & \\
\hline proximity to public facilities $\left(C_{4}\right)$ & 2.032 & 2.125 & 4.156 & -0.093 & 0.200 & $0.070(10)$ \\
\hline proximity to the community $\left(C_{5}\right)$ & 2.201 & 1.861 & 4.062 & 0.340 & 0.175 & $0.061(12)$ \\
\hline proximity to commercial area $\left(C_{6}\right)$ & 2.520 & 2.226 & 4.746 & 0.294 & 0.207 & $0.073(9)$ \\
\hline proximity to schools $\left(C_{7}\right)$ & 2.086 & 1.950 & 4.036 & 0.135 & 0.183 & $0.064(11)$ \\
\hline agglomeration effect $\left(C_{8}\right)$ & 2.387 & 2.456 & 4.843 & -0.068 & 0.235 & $0.082(4)$ \\
\hline Shop traits $\left(D_{3}\right)$ & 11.157 & 13.412 & 24.569 & -2.255 & 0.434 & \\
\hline types of shop $\left(C_{9}\right)$ & 2.497 & 2.321 & 4.818 & 0.176 & 0.182 & $0.079(6)$ \\
\hline sizes of shop $\left(C_{10}\right)$ & 2.039 & 2.386 & 4.425 & -0.347 & 0.182 & $0.079(6)$ \\
\hline rent $\left(C_{11}\right)$ & 2.409 & 3.216 & 5.626 & -0.807 & 0.221 & $0.096(1)$ \\
\hline business hours $\left(C_{12}\right)$ & 1.838 & 2.585 & 4.424 & -0.747 & 0.197 & $0.085(3)$ \\
\hline visibility $\left(C_{13}\right)$ & 2.374 & 2.903 & 5.277 & -0.530 & 0.219 & $0.095(2)$ \\
\hline
\end{tabular}

\subsection{Potential performance and GAP for the three alternatives based on modified VIKOR methodology}

Three alternative BTSs, located in Nanjing, were evaluated based on DANP weights reached in combination with a modified VIKOR methodology (see Table 10 for overall results). In terms of the GAP ratio (performance) for the criteria, the minimum GAP for alternative B is 0.312 (6.883) for Site traits $\left(D_{2}\right)$, followed by 0.368 (6.315) for Traffic traits $\left(D_{1}\right)$ and lastly 0.404 (5.965) for Shop traits $\left(D_{3}\right)$. The minimum expected GAP in alternative $\mathrm{C}$ is 0.402 (5.976) for Shop traits $\left(D_{3}\right)$, followed by 0.406 (5.939) for Site traits $\left(D_{2}\right)$, and, lastly, 0.431 (5.685) for Traffic traits $\left(D_{1}\right)$. In alternative A, 0.403 (5.973) of Shop traits $\left(D_{3}\right)$ was the lowest GAP value, followed by 0.412 (5.876) for Site traits $\left(D_{2}\right)$, with the largest GAP value presented by Traffic traits' $\left(D_{1}\right) 0.430$ (5.697).

The criteria with larger GAP values (lower performance value) among the three alternatives are proposed. In alternative $\mathrm{B}$, rents' $\left(C_{11}\right)$ value of $0.629(3.714)$ is the largest GAP ratio, followed by 0.529 (4.714) for types of shop $\left(C_{9}\right)$ and $0.343(6.571)$ for proximity to schools $\left(C_{7}\right)$. In alternative $C$, the largest GAP ratio is 0.514 (4.857), which corresponds to proximity to public transportation systems $\left(C_{1}\right)$, followed by $0.500(5.000)$ for visibility $\left(C_{13}\right)$ and 0.486 (5.143) for sizes of shop $\left(C_{10}\right)$. In alternative A, the largest GAP ratio is $0.529(4.714)$ for proximity to commercial areas $\left(C_{6}\right)$, followed by $0.471(5.286)$ for proximity to a street corner $\left(C_{2}\right)$ and $0.443(5.571)$ for types of shop $\left(C_{9}\right)$.

Overall, the performance values of alternatives $\mathrm{A}, \mathrm{B}$, and $C$ are 5.882, 6.365, and 5.903, respectively. Simulating results under different decision-making parameters $v$ is indicated via Table 11. Based on the individual leastregret principle (i.e. when $v=0$ ), the integrated value $R_{k}$ is $0.529,0.629$, and 0.514 , respectively. When considering the average decision-making principle (i.e. when $v=0.5$ ), the three cases present values of $0.471,0.496$ and 0.462 , respectively. The integrated value based on the group maximum utility principle (i.e. when $v=1$ ) are $0.412,0.363$ and 0.410 , respectively.

Table 10. Performance and GAP ratios for three pre-selected cases in Nanjing

\begin{tabular}{|l|c|c|c|c|c|c|}
\hline \multirow{2}{*}{ Dimension/Criteria } & \multicolumn{3}{|c|}{ Performance } & \multicolumn{3}{c|}{ GAP (ratio) } \\
\cline { 2 - 7 } & $\mathrm{A}$ & $\mathrm{B}$ & $\mathrm{C}$ & $\mathrm{A}$ & $\mathrm{B}$ & $\mathrm{C}$ \\
\hline Traffic traits $\left(D_{1}\right)$ & 5.697 & 6.315 & 5.685 & 0.430 & 0.368 & 0.431 \\
\hline proximity to public transportation system $\left(C_{1}\right)$ & 6.000 & 7.714 & 4.857 & 0.400 & 0.229 & 0.514 \\
\hline proximity to a street corner $\left(C_{2}\right)$ & 5.286 & 7.714 & 6.571 & 0.471 & 0.229 & 0.343 \\
\hline road width $\left(C_{3}\right)$ & 5.714 & 7.143 & 5.429 & 0.429 & 0.286 & 0.457 \\
\hline
\end{tabular}


End of Table 10

\begin{tabular}{|l|c|c|c|c|c|c|}
\hline \multirow{2}{*}{ Dimension/Criteria } & \multicolumn{2}{|c|}{ Performance } & \multicolumn{3}{c|}{ GAP (ratio) } \\
\cline { 2 - 6 } & $\mathrm{A}$ & $\mathrm{B}$ & $\mathrm{C}$ & $\mathrm{A}$ & $\mathrm{B}$ & $\mathrm{C}$ \\
\hline Site traits $\left(D_{2}\right)$ & 5.876 & 6.882 & 5.939 & 0.412 & 0.312 & 0.406 \\
\hline proximity to public facilities $\left(C_{4}\right)$ & 5.571 & 7.857 & 5.857 & 0.443 & 0.214 & 0.414 \\
\hline proximity to the community $\left(C_{5}\right)$ & 6.000 & 7.571 & 7.143 & 0.400 & 0.243 & 0.286 \\
\hline proximity to commercial area $\left(C_{6}\right)$ & 4.714 & 8.286 & 5.857 & 0.529 & 0.171 & 0.414 \\
\hline proximity to schools $\left(C_{7}\right)$ & 7.429 & 6.571 & 5.429 & 0.257 & 0.343 & 0.457 \\
\hline agglomeration effect $\left(C_{8}\right)$ & 5.857 & 8.429 & 6.000 & 0.414 & 0.157 & 0.400 \\
\hline Shop traits $\left(D_{3}\right)$ & 5.973 & 5.965 & 5.976 & 0.403 & 0.404 & 0.402 \\
\hline types of shop $\left(C_{9}\right)$ & 5.571 & 6.571 & 6.286 & 0.443 & 0.343 & 0.371 \\
\hline sizes of shop $\left(C_{10}\right)$ & 6.143 & 4.714 & 5.143 & 0.386 & 0.529 & 0.486 \\
\hline rent $\left(C_{11}\right)$ & 6.143 & 3.714 & 6.714 & 0.386 & 0.629 & 0.329 \\
\hline business hours $\left(C_{12}\right)$ & 6.286 & 7.143 & 6.714 & 0.371 & 0.286 & 0.329 \\
\hline visibility $\left(C_{13}\right)$ & 5.714 & 7.714 & 5.000 & 0.429 & 0.229 & 0.500 \\
\hline Total performance & 5.882 & 6.365 & 5.903 & & & 0.412 \\
\hline Total gap & & & & 0.363 & 0.410 \\
\hline Maximum gap & & & & 0.529 & 0.629 & 0.514 \\
\hline
\end{tabular}

Table 11. Intergraded value $R_{k}$ under different decision-making parameters $v$

\begin{tabular}{|c|c|c|c|}
\hline Alternative & \multicolumn{3}{|c|}{$R_{k}$} \\
\hline$v$ & $\mathrm{~A}$ & $\mathrm{~B}$ & $\mathrm{C}$ \\
\hline 0.00 & 0.529 & 0.629 & 0.514 \\
\hline 0.10 & 0.517 & 0.602 & 0.504 \\
\hline 0.20 & 0.506 & 0.576 & 0.493 \\
\hline 0.30 & 0.494 & 0.549 & 0.483 \\
\hline 0.40 & 0.482 & 0.523 & 0.472 \\
\hline 0.50 & 0.471 & 0.496 & 0.462 \\
\hline 0.60 & 0.459 & 0.469 & 0.452 \\
\hline 0.70 & 0.447 & 0.443 & 0.441 \\
\hline 0.80 & 0.435 & 0.416 & 0.431 \\
\hline 0.90 & 0.424 & 0.390 & 0.420 \\
\hline 1.00 & 0.412 & 0.363 & 0.410 \\
\hline
\end{tabular}

\section{Discussion}

The two primary findings are discussed as follow.

\subsection{Influential relationships among criteria and key location determinants concerning BTSs}

The INRM results obtained via DEMATEL (see Figure 3) indicate that traffic traits $\left(D_{1}\right)$ and site traits $\left(D_{2}\right)$ with positive values of $(d+r)$ are key determinants affecting a BTS; in this regard, traffic traits $\left(D_{1}\right)$ affect site traits $\left(D_{2}\right)$, while shop traits $\left(D_{3}\right)$ are affected by both of the aforementioned. This echoes the viewpoint of retail location theory (Reilly, 1929, 1931; Christaller, 1933, 1966; Alonso, 1964). By playing a connecting role between concerns of accessibility and food outlets, traffic traits $\left(D_{1}\right)$ promote accessibility of location (Tzeng et al., 2002; Lin \& Yang,
2019). By contrast, shop traits (D3), which present with a negative $(d+r)$, is not an important determinant of BTS, although DANP methodology indicates that this category carries the highest weight. These interactions clearly identify the location determinants that are core to BTSs and highlight the advantages of this method.

Following the same logic, all the criteria of traffic traits $\left(D_{1}\right)$ have positive $(d+r)$ values, except for proximity to public facilities $\left(C_{4}\right)$ and the agglomeration effect $\left(C_{8}\right)$. Proximity to a street corner $\left(C_{2}\right)$ shows a larger positive value than has been presented elsewhere (Kuo et al., 1999, 2002; Chen \& Tsai, 2016), while proximity to public transportation systems $\left(C_{1}\right)$ (Tzeng et al., 2002; Chen et al., 2018; Lin \& Yang, 2019) and road width $\left(C_{3}\right)$ (Sevtsuk, 2014; Oh et al., 2015) are consistent with the results from the literature. Road width $\left(C_{3}\right)$ highlights the higher DANP weights among these criteria, indicating that the interviewed experts believe that road width still has a very important influence on BTS customers who mainly make purchases in person. In addition, the type of shop $\left(C_{9}\right)$, ranked sixth based on its DANP weight-has a positive $(d+r)$ value, indicating that its importance cannot be ignored. This result supports the phenomenon whereby BTSs are often found in large shopping malls in many new development zones but are street-based throughout older China cities.

The criteria related to site traits $\left(D_{2}\right)$ verify that BTSs have become an important part of the daily dietary routines of urban residents in China and Taiwan. It is easy to observe a large number of BTSs across various environments, such as residential areas, commercial areas, or school areas. This also echoes the results from Westerndominated public health research that focuses upon the higher number and density of locations that sell sugary food around commercial areas (Day \& Pearce, 2011; Engler-Stringer et al., 2014; Yang et al., 2017), communities 
(He et al., 2012; Smith et al., 2013), and schools (Day et al., 2015). Compared to the previous literature regarding restaurants' location-with a focus on business areas (Tzeng et al., 2002; Chen \& Tsai, 2016; Chen et al., 2018)-the exploration of site-relevant factors is an innovative approach taken by this research and can give operators a good set of investment guidelines. This also carries implications for the expansion of healthcare research in the prevailing Western-oriented food environment. This is particularly salient given that, although a large number of Western-oriented research fields have shown the relationship between the location of sugary food outlets and health, research focusing on BTSs is lacking. At present, only Tseng et al. (2014) have found that college students who drink more tea in Taiwan have a higher Body Mass Index (BMI), implying that this interesting phenomenon is related to BTSs' business operations. However, it remains a complex issue because BTSs' sell not only tea but also a variety of sugary beverages. Therefore, active and in-depth exploration of the public health evidence concerning the relationship between intake behavior (such as type, frequency, and amount of BTS product intake) and health status (such as the prevalence of overweight, obesity, or even cardiovascular disease) is meaningful in expanding the academic understanding of these phenomena and in promoting public health.

The relative position of the agglomeration effect $\left(C_{8}\right)$ is interesting. The negative value calculated via $(d+r)$ means that it is influenced by other determinants and is thus not the main determinant. This also implies that operators of BTSs may be less willing to agglomerate with each other, given the bigger risks that accompany competition, as reported in the literature (Kuo et al., 1999, 2002; Tzeng et al., 2002; Prayag et al., 2012; Ho et al., 2013; John et al., 2015; Chen \& Tsai, 2016; Chen et al., 2018). However, the agglomeration phenomenon of BTSs that is often observed seems to be explained by the "comparison of goods" effect, based on reducing search costs (Hotelling, 1929; Sevtsuk, 2014). This study proposes that different BTSs actually display various beverage features and business strategies despite selling products made of similar inputs (such as tea-making ingredients). Consequently, consumers decide which BTS is more suited to their desires or needs through a process of selection. Another interesting finding is that rent $\left(C_{11}\right)$ carries the highest weighting (via the DANP method), echoing the current literature, including Tzeng et al. (2002), Chen and Tsai (2016), and Chen et al. (2019). More important, negative $(d+r)$ values (based on the DEMATEL method) imply that rents belong with the "effect" group. This is a reasonable finding because higher rents are impacted by better traffic, site, or store transit, meaning that it is not difficult to find an agglomeration of BTSs among locations with higher rents in some commercial areas (see Figure 1). This is because shops with better traffic and site transit may acquire more potential customers, even if higher rents come as a tradeoff.

In summary, traffic traits $\left(D_{1}\right)$ and site traits $\left(D_{2}\right)$, along with relevant criteria, are the key factors in explaining the choice made by BTSs in location determination and will affect shop traits $\left(D_{3}\right)$ and the relevant set of criteria. Specifically, key location determinants for BTSs (as presented by the DEMATEL method, combined with the DANP process) include proximity to public transportation systems $\left(C_{1}\right)$, proximity to a street corner $\left(C_{2}\right)$, road width $\left(C_{3}\right)$, proximity to the community $\left(C_{5}\right)$, proximity to commercial areas $\left(C_{6}\right)$, proximity to schools $\left(C_{7}\right)$, and type of shop $\left(C_{9}\right)$. After BTSs address these determinants, the other factors will be improved, making the location more attractive for BTS operators.

\subsection{Different decision-making ranking and improvement strategies for three alternatives in Nanjing}

A modified VIKOR methodology was used to evaluate GAP values' potential performance for the three pre-selected alternatives located in Nanjing, China. Simultaneously, the DEMATEL method's results could also provide and form effective improvement strategies to indicate the effectiveness of a BTS location while evaluating alternatives. Among the three alternatives, alternative $\mathrm{B}$ has the highest performance value, followed by alternative A, with the worst performer being alternative $\mathrm{C}$. When considering different decision-making strategies, different sorting methods were also presented. When considering only the individual maximum benefit, the ranking is $\mathrm{B}>\mathrm{A}>\mathrm{C}$. As more group benefits are considered, the ranking changes when $v=0.7$. At this time, the ranking is altered to $\mathrm{A}>\mathrm{B}>\mathrm{C}$. When considering the maximum group benefit, the ranking is presented as $\mathrm{A}>\mathrm{C}>\mathrm{B}$. Such results reflect the advantages of this method used in this study, offering decision-makers different evaluation suggestions according to their needs.

In terms of improvement strategies, rent $\left(C_{11}\right)$, size of the shop $\left(C_{10}\right)$, and proximity to schools $\left(C_{7}\right)$ had lower performance values (larger GAP ratios) in the case of alternative B. Based on guidance from the DEMATEL method, an improvement in criteria with characteristics that influence others and those demonstrating lower performance-such as proximity to schools $\left(C_{7}\right)$ and road width $\left(C_{3}\right)$-will further enhance the advantages of BTS locations. Following this logic, alternative $\mathrm{C}$ should focus on improving its proximity to public transportation systems $\left(C_{1}\right)$, proximity to schools $\left(C_{7}\right)$, road width $\left(C_{3}\right)$, and proximity to commercial areas $\left(C_{6}\right)$. In alternative $A$, proximity to commercial areas $\left(C_{6}\right)$, proximity to a street corner $\left(C_{2}\right)$, proximity to the community $\left(C_{5}\right)$, types of shops $\left(C_{9}\right)$, proximity to public transportation systems $\left(C_{1}\right)$, and road width $\left(C_{3}\right)$ should be focused upon to improve the BTS's potential.

\section{Conclusions and research outlook}

This work started by improving upon the traditional MADM methods (such as AHP and ANP)-which did not fully consider the mutual influences involved when exploring retail location determinants-for use with BTSs 
(having oriental cultural characteristics, especially in China and Taiwan), thus forming a unique research objective. Although Western literature has explored the location of food retail industries, such as fast-food restaurants and convenience stores, this study is, as far as the author knows, the first to explore unique food retailing industries, such as that of BTSs. The hybrid MADM model is proposed as combining the advantages of three decisionmaking methods to provide decision-makers with better frameworks for thinking about evaluating the location determinants of BTSs, the potential offered by different locations, and the countermeasures needed, using scientific and systematic methods.

The decision-making model proposed via this research can improve and solve several traditional decision-making problems for location evaluation; this is one of the paper's most prominent contributions. First, the DEMATEL method's introduction can clarify the influential relationship between location determinants and provide decisionmakers a way to identify each determinant's attribute, such as to cause and effect relations. This method corrects the unrealistic assumption of non-interacting factors related to traditional regression models (Yang et al., 2017) and AHP (Kuo et al., 1999, 2002; Tzeng et al., 2002; Ho et al., 2013; Ylldız \& Tüysüz, 2019). Second, the DEMATEL method and the traditional ANP process can make a more realistic DANP method to evaluate actual alternatives. The DANP method, combined with DEMATEL and ANP processes, improves upon the traditional ANP method (Tolga et al., 2013; Neumüller et al., 2015; Wibisono \& Marella, 2020). In addition, DEMATEL and DANP processes can also comprehensively identify the key location determinants. Third, a modified VIKOR methodology will also help decision-makers evaluate several BTS alternatives based on different perspectives (such as individuals or groups). More importantly, the INRM formed in combination with the DEMATEL method can provide decisionmakers with a good way of identifying the indicators to be prioritized under settings of limited resources to improve performance. Overall, this study should be considered groundbreaking research exploring location determinants for food outlets, based upon a hybrid MADM model and those playing a key role in location selection for operators of BTSs. Further applications of this paper's approach to various food outlets across different regions are recommended to compare and strengthen the supporting evidence of the model's applicability. In addition, this model can be further optimized in future research by, for example, combining it with fuzzy semantics, making it a closer approximation of people's real decision-making processes.

Another major contribution of this study is its exploration of BTSs, the first of its kind. Following this, future work concerning BTSs is proposed. With the rapid development of BTSs in Western cities in recent years, the BTS industry has gradually become familiar to Western urban residents. Future research can use Western cities as a research context to explore differences in this study's results. Such research could provide a better understanding for foreign investment endeavors in the BTS industry to avoid business promotion failures. In addition, representative retail location theories, such as spatial interaction theory, reveal that merchant factors (such as products, brands, and operations) will become an important factor in weighing distance and consumer behavior. Subsequent research can further utilize big data such as geographic information systems (GIS), for example, and combine it with multiple data sources, such as consumer behavior questionnaires, to explore the relationships between individual factors for different businesses, such as franchise operations, or marketing approaches. In addition, studying the behavioral motivations and intentions of consumers is critical for BTSs when formulating the industry's business management strategies.

\section{Funding}

This work was supported by the National Natural Science Foundation of China under Grant [numbers 41701608 and 41771189]; Hungry Cities Partnership project supported by the Social Sciences and Humanities under Grant [number 895-2013-3005]; and International Partnerships for Sustainable Societies (IPaSS) Program supported by International Development Research Centre under Grant [number 107775-001].

\section{Author contributions}

Sheng-Hau LIN and Taiyang, ZHONG conceived the study and were responsible for the design and development of the data analysis. Xiwei HE, and Jia-Hsuan LI were responsible for data collection and interpretation. Gwo-Hshiung TZENG was responsible for modeling MADM. Chih-Chen HSU, Jing-Chzi HSIEH and Taiyang, ZHONG were responsible for manuscript's revision. Sheng-Hau LIN wrote the first draft of the article.

\section{Disclosure statement}

Authors do not have any competing financial, professional, or personal interests from other parties.

\section{References}

Adjoian, T., Dannefer, R., Sacks, R., \& Van Wye, G. (2014). Comparing sugary drinks in the food retail environment in six NYC neighborhoods. Journal of Community Health, 39, 327-335. https://doi.org/10.1007/s10900-013-9765-y

Alonso, W. (1964). Location and land use: toward a general theory of land rent. Harvard University Press.

https://doi.org/10.4159/harvard.9780674730854

Austin, S. B., Melly, S. J., Sanchez, B. N., Patel, A., Buka, S., \& Gortmaker, S. L. (2005). Clustering of fast-food restaurants around schools: a novel application of spatial statistics to the study of food environments. American Journal of Public Health, 95(9), 1575-1581.

https://doi.org/10.2105/AJPH.2004.056341

Brown, S. (1993). Retail location theory: evolution and evaluation. International Review of Retail Distribute Consumer Research, 3(2), 185-229. https://doi.org/10.1080/09593969300000014 
Chen, J., Wang, J., Baležentis, T., Zagurskaite, F., Streimikiene, D., \& Makutènienė, D. (2018). Multicriteria approach towards the sustainable selection of a teahouse location with sensitivity analysis. Sustainability, 10, 2926. https://doi.org/10.3390/su10082926

Chen, L. F., \& Tsai, C. T. (2016). Data mining framework based on rough set theory to improve location selection decisions: a case study of a restaurant chain. Tourism Management, 53, 197-206. https://doi.org/10.1016/j.tourman.2015.10.001

Chen, T. C., Lin, C. L., \& Tzeng, G. H. (2019). Assessment and improvement of wetlands environmental protection plans for achieving sustainable development. Environmental Research, 169, 280-296. https://doi.org/10.1016/j.envres.2018.10.015

Chiang, P. H., Wahlqvist, M. L., Lee, M. S., Huang, L. Y., Chen, H. H., \& Huang, T. Y. (2011). Fast-food outlets and walkability in school neighbourhoods predict fatness in boys and height in girls: a Taiwanese population study. Public Health Nutrition, 14(9), 1601-1609.

https://doi.org/10.1017/S1368980011001042

Chou, T. Y., Hsu, C. L., \& Chen, M. C. (2008). A fuzzy multi-criteria decision model for international tourist hotels location selection. International Journal of Hospitality Management, 27(2), 293-301. https://doi.org/10.1016/j.ijhm.2007.07.029

Christaller, W. (1933). Die zentralen Orte in Süddeutschland. Gustav Fischer.

Christaller, W. (1966). Central places in Southern Germany. Prentice-Hall Press.

Chathoth, P. K., \& Olsen, M. D. (2007). The effect of environment risk, corporate strategy, and capital structure on firm performance: an empirical investigation of restaurant firms. International Journal of Hospitality Management, 26(3), 502516. https://doi.org/10.1016/j.ijhm.2006.03.007

Cutumisu, N., Traoré, I., Paquette, M. C., Cazale, L., Camirand, H., Lalonde, B., \& Robitaille, E. (2017). Association between junk food consumption and fast-food outlet access near school among Quebec secondary-school children: findings from the Quebec Health Survey of High School Students (QHSHSS) 2010-11. Public Health Nutrition, 20(5), 927-937. https://doi. org/10.1017/S136898001600286X

Day, P. L., Pearce, J. R., \& Pearson, A. L. (2015). A temporal analysis of the spatial clustering of food outlets around schools in Christchurch, New Zealand, 1966 to 2006. Public Health Nutrition, 181, 135-142.

https://doi.org/10.1017/S1368980013002863

Day, P. L., \& Pearce, J. (2011). Obesity-promoting food environments and the spatial clustering of food outlets around schools. American Journal of Preventive Medicine, 40, 113 121. https://doi.org/10.1016/j.amepre.2010.10.018

Dehe, B., \& Bamfor, D. (2015). Development, test and comparison of two multiple criteria decision analysis (MCDA) models: a case of healthcare infrastructure location. Expert Systems with Applications, 42(19), 6717-6727.

https://doi.org/10.1016/j.eswa.2015.04.059

Dock, J. P., Song, W., \& Lu, J. (2015). Evaluation of dine-in restaurant location and competitiveness: applications of gravity modeling in Jefferson County, Kentucky. Applied Geography, 60, 204-209. https://doi.org/10.1016/j.apgeog.2014.11.008

dos Santos, P. H., Neves, S. M., Sant’Anna, D. O., de Oliveira, C. H., \& Carvalho, H. D. (2019). The analytic hierarchy process supporting decision making for sustainable development: an overview of applications. Journal of Cleaner Production, 212, 119-138.

https://doi.org/10.1016/j.jclepro.2018.11.270
Duran, A. C., de Almeida, S. L., do Rosario DO Latorre, M., \& Jaime, P. C. (2016). The role of the local retail food environment in fruit, vegetable and sugar-sweetened beverage consumption in Brazil. Public Health Nutrition, 19(6), 10931102. https://doi.org/10.1017/S1368980015001524

Eaton, B. C., \& Lipsey, R. G. (1975). The principle of minimum differentiation reconsidered: some new developments in the theory of spatial competition. Review of Economic Studies, 42, 27-49. https://doi.org/10.2307/2296817

Engler-Stringer, R., Shah, T., Bell, S., \& Muhajarine, N. (2014). Geographic access to healthy and unhealthy food sources for children in neighbourhoods and from elementary schools in a mid-sized Canadian city. Spatial and Spatio-temporal Epidemiology, 11, 23-32. https://doi.org/10.1016/j.sste.2014.07.001

Fisher, D. P. (1997). Location, location, location: ensuring a franchisee's success. Hospitality Review Journal, 15(1), 4.

https://digitalcommons.fiu.edu/hospitalityreview/vol15/iss1/4

Fleischhacker, S. E., Evenson, K. R., Rodriguez, D. A., \& Ammerman, A. S. (2013). A systematic review of fast food access studies. Obesity Reviews, 12, e460-e471. https://doi.org/10.1111/j.1467-789X.2010.00715.x

Fortune Business Insights. (2019). Bubble tea: global market analysis, insights and forecast, 2019-2026.

https://www.fortunebusinessinsights.com/

Fraser, L. K., Edwards, K. L., Cade, J., \& Clarke, G. P. (2010). The geography of fast food outlets: a review. International Journal of Environmental Research and Public Health, 7, 2290-2308. https://doi.org/10.3390/ijerph7052290

Gabus, A., \& Fontela, E. (1972). World problems, an invitation to further thought within the framework of DEMATEL. Battelle Geneva Research Centre Press.

Gabus, A., \& Fontela, E. (1973). Perceptions of the world problematique: communication procedure, communicating with those bearing collective responsibility. Battelle Geneva Research Centre Press.

Gölcük, I., \& Baykasoĝlua, A. (2016). An analysis of DEMATEL approaches for criteria interaction handling within ANP. Expert Systems with Applications, 46, 346-366.

https://doi.org/10.1016/j.eswa.2015.10.041

He, M., Tucker, P., Gilliland, J., Irwin, J. D., Larsen, K., \& Hess, P. (2012). The influence of local food environments on adolescents' food purchasing behaviors. International Journal of Environmental Research and Public Health, 9, 1458-1471. https://doi.org/10.3390/ijerph9041458

Ho, H. P., Chang, C. T., \& Ku, C. Y. (2013). On the location selection problem using analytic hierarchy process and multi-choice goal programming. International Journal of Systems Science, 44(1), 94-108. https://doi.org/10.1080/00207721.2011.581397

Hotelling, H. (1929). Stability in competition. The Economic Journal, 39(153), 41-57. https://doi.org/10.2307/2224214

John, T. S., Jones, M. F., \& Botieff, M. (2015). Where restaurants fail: a longitudinal study of micro locations. Journal of Foodservice Business Research, 18(4), 328-340. https://doi.org/10.1080/15378020.2015.1068670

Kheybari, S., Rezaie, F. M., \& Farazmand, H. (2020). Analytic network process: an overview of applications. Applied Mathematics and Computation, 367, 124780. https://doi.org/10.1016/j.amc.2019.124780

Kuo, M. (2011). Optimal location selection for an international distribution center by using a new hybrid method. Expert Systems with Applications, 38(6), 7208-7221. https://doi.org/10.1016/j.eswa.2010.12.002 
Kuo, R. J., Chi, S. C., \& Kao, S. S. (1999). A decision support system for locating convenience store through fuzzy AHP. Computers \& Industrial Engineering, 37(12), 323-326. https://doi.org/10.1016/S0360-8352(99)00084-4

Kuo, R. J., Chi, S. C., \& Kao, S. S. (2002). A decision support system for selecting convenience store location through integration of fuzzy AHP and artificial neural network. Computers in Industry, 47(2), 199-214. https://doi.org/10.1016/S0166-3615(01)00147-6

Lan, Y. H. (2017). The sweet taste of familiar: Taipei pearl milk tea consumer and identity. Department of Sociology, Soochow University (in Chinese).

Lin, C. Y., \& Tzeng, H. Y. (2010). Research on local food globalization in Taiwan: the meaning of pearl milk tea among college students. Cross-cultural Studies, 1(4), 37-61 (in Chinese).

Lin, J. J., \& Yang, S. H. (2019). Proximity to metro stations and commercial gentrification. Transport Policy, 77, 79-89. https://doi.org/10.1016/j.tranpol.2019.03.003

Lin, S. H., Wang, D., Huang, X., Zhao, X., Hsieh, J. C., Tzeng, G. H., Li, J. H., \& Chen, J. T. (2021). A multi-attribute decision-making model for improving inefficient industrial parks. Environment, Development and Sustainability, 23, 887921. https://doi.org/10.1007/s10668-020-00613-4

Liu, K. M., Lin, S. H., Hsieh, J. C., \& Tzeng, G. H. (2018a). Improving the food waste composting facilities site selection for sustainable development using a hybrid modified MADM model. Waste Management, 75, 44-59.

https://doi.org/10.1016/j.wasman.2018.02.017

Liu, Y., Wang, H., \& Tzeng, G. H. (2018b). From measure to guidance: galactic model and sustainable development planning toward the best smart city. Journal of Urban Planning and Development, 144(4), 04018035.

https://doi.org/10.1061/(ASCE)UP.1943-5444.0000478

Maimaiti, M., Ma, X., Zhao, X., Jia, M., Li, J., Yang, M., Ru, Y., Yang, F., Wang, N., \& Zhu, S. (2020). Multiplicity and complexity of food environment in China: full-scale field census of food outlets in a typical district. European Journal of Clinical Nutrition, 74, 390-408.

https://doi.org/10.1038/s41430-019-0462-5

Maimaiti, M., Zhao, X., Jia, M., Ru, Y., \& Zhu, S. (2018). How we eat determines what we become: opportunities and challenges brought by food delivery industry in a changing world in China. Journal of Clinical Nutrition, 72, 1282-1286. https://doi.org/10.1038/s41430-018-0191-1

Ministry of Finance, R.O.C. (2018). https://findbiz.nat.gov.tw/fts/ query/QueryBar/queryInit.do

Murphy, M., Badland, H., Jordan, H., Koohsari, M. J., \& GilesCorti, B. (2018). Local food environments, suburban development, and BMI: a mixed methods study. International Journal of Environmental Research and Public Health, 15, 1392. https://doi.org/10.3390/ijerph15071392

Neumüller, C., Kellner, F., Gupta, J. N. D., \& Lasch, R. (2015). Integrating three-dimensional sustainability in distribution centre selection: the process analysis method-based analytic network process. International Journal of Production Research, 53(2), 409-434. https://doi.org/10.1080/00207543.2014.939241

Oh, S. J., Lee, J. H., Kim, H. K., \& Shin, J. (2015). Sales determinants of restaurant chain business: focused on family restaurants in Korea. Indian Journal of Science and Technology, 8(23), 1-7. https://doi.org/10.17485/ijst/2015/v8i23/79228

Opricovic, S., \& Tzeng, G. H. (2004). Compromise solution by MCDM methods: a comparative analysis of VIKOR and TOPSIS. European Journal of Operational Research, 156(2), 445-455. https://doi.org/10.1016/S0377-2217(03)00020-1
Opricovic, S., \& Tzeng, G. H. (2007). Extended VIKOR method in comparison with outranking methods. European Journal of Operational Research, 178(2), 514-529.

https://doi.org/10.1016/j.ejor.2006.01.020

Ou Yang, Y. P., Shieh, Y. P., \& Tzeng, G. H. (2013). A VIKOR technique based on DEMATEL and ANP for information security risk control assessment. Information Sciences, 232, 482-500. https://doi.org/10.1016/j.ins.2011.09.012

Özcan, T., Çelebi, N., \& Esnaf, S. (2011). Comparative analysis of multi-criteria decision making methodologies and implementation of a warehouse location selection problem. Expert Systems with Applications, 38(8), 9773-9779. https://doi.org/10.1016/j.eswa.2011.02.022

Park, K., \& Khan, M. A. (2006). An exploratory study to identify the site selection factors for US franchise restaurants. Journal of Foodservice Business Research, 8(1), 97-114. https://doi.org/10.1300/J369v08n01_07

Parsa, H. G., Self, J. T., Njite, D., \& King, T. (2005). Why restaurants fail. Cornell Hotel and Restaurant Administration Quarterly, 46(3), 304-322. https://doi.org/10.1177/0010880405275598

Peng, K. H., \& Tzeng, G. H. (2019). Exploring heritage tourism performance improvement for making sustainable development strategies using the hybrid-modified MADM model. Current Issues in Tourism, 22(8), 921-947. https://doi.org/10.1080/13683500.2017.1306030

Prayag, G., Landré, M., \& Ryan, C. (2012). Restaurant location in Hamilton, New Zealand: clustering patterns from 1996 to 2008. International Journal of Contemporary Hospitality Management, 24(3), 430-450. https://doi.org/10.1108/09596111211217897

Qin, X., Zhen, F., \& Gong, Y. (2019). Combination of big and small data: empirical study on the distribution and factors of catering space popularity in Nanjing, China. Journal of Urban Planning and Development, 145(1), 05018022. https://doi.org/10.1061/(ASCE)UP.1943-5444.0000489

Ran, L. N. (2018). Běi jīng năi chá xiāo fèi diào chá: 80hòu 90hòu gòng xiàn jìn 9chéng pái zhăng duì chéng zuì dà cáo diăn. http://www.sohu.com/a/249614350_393779 (in Chinese).

Reilly, W. J. (1929). Methods for the study of retail relationships. University of Texas, Bureau of Business Research Press.

Reilly, W. J. (1931). The law of retail gravitation. Knickerbrocker Press.

Saaty, T. L. (1980). The analytic hierarchy process. McGraw-Hill Press. https://doi.org/10.21236/ADA214804

Saaty, T. L. (1996). The analytic network process. RWS Publications Press.

Sevtsuk, A. (2014). Location and agglomeration: the distribution of retail and food businesses in dense urban environments. Journal of Planning Education and Research, 34(4), 374-393. https://doi.org/10.1177/0739456X14550401

Shahi, E., Alavipoor, F. S., \& Karimi, S. (2018). The development of nuclear power plants by means of modified model of fuzzy DEMATEL and GIS in Bushehr, Iran. Renewable and Sustainable Energy Reviews, 83, 33-49.

https://doi.org/10.1016/j.rser.2017.10.073

Shen, K. Y., \& Tzeng, G. H. (2018). Advances in multiple criteria decision making for sustainability: modeling and applications. Sustainability, 10(5), 1600. https://doi.org/10.3390/su10051600

Shi, G., Shan, J., Ding, L., Ye, P., Li, Y., \& Jiang, N. (2019). Urban road network expansion and its driving variables: a case study of Nanjing City. International Journal of Environmental Research and Public Health, 16, 2318. https://doi.org/10.3390/ijerph16132318 
Smith, D., Cummins, S., Clark, C., \& Stansfeld, S. (2013). Does the local food environment around schools affect diet? Longitudinal associations in adolescents attending secondary schools in East London. BMC Public Health, 13, 70. https://doi.org/10.1186/1471-2458-13-70

Smith, S. L. J. (1983). Restaurants and dining out: geography of a tourism business. Annals of Tourism Research, 10(4), 515-549. https://doi.org/10.1016/0160-7383(83)90006-3

Smith, S. L. J. (1985). Location patterns of urban restaurants. Annals of Tourism Research, 12(4), 581-602. https://doi.org/10.1016/0160-7383(85)90079-9

Subramanian, N., \& Ramanathan, R. (2012). A review of applications of analytic hierarchy process in operations management. International Journal of Production Economics, 138(2), 215-241. https://doi.org/10.1016/j.ijpe.2012.03.036

Tolga, A. C., Tuysuz, F., \& Kahraman, C. (2013). A fuzzy multicriteria decision analysis approach for retail location selection. International Journal of Information Technology and Decision Making, 12(4), 729-755.

https://doi.org/10.1142/S0219622013500272

Trivedi, A. (2018). A multi-criteria decision approach based on DEMATEL to assess determinants of shelter site selection in disaster response. International Journal of Disaster Risk Reduction, 31, 722-728. https://doi.org/10.1016/j.ijdrr.2018.07.019

Tsai, P. M. (2019). Y̌n liào diàn 10nián chéng zhăng 9000jiā yè zhě zuì pà liú bú zhù rén. https://www.cna.com.tw/news/firstnews/201907060122.aspx (in Chinese).

Tseng, H. C., Wang, C. J., Cheng, S. H., Sun, Z. J., Chen, P. S., Lee, C. T., Lin, S. H., Yang, Y. K., \& Yang, Y. C. (2014). Teadrinking habit among new university students: associated factors. Kaohsiung Journal of Medical Sciences, 30, 98-103. https://doi.org/10.1016/j.kjms.2013.08.004

Tzeng, G. H., \& Shen, K. Y. (2017). New concepts and trends of hybrid multiple criteria decision making. CRC Press. https://doi.org/10.1201/9781315166650

Tzeng, G. H., Teng, M. H., Chen, J. J., \& Opricovic, S. (2002). Multicriteria selection for a restaurant location in Taipei. International Journal of Hospitality Management, 21, 171-187. https://doi.org/10.1016/S0278-4319(02)00005-1

Wibisono, Y. Y., \& Marella, S. (2020). A decision making model for selection of café location: an ANP approach. Journal of Physics: Conference Series, 1477, 052030.

https://doi.org/10.1088/1742-6596/1477/5/052030

Widener, M. J., Minaker, L., Farber, S., Allen, J., Vitali, B., Coleman, P. C., \& Cook, B. (2017). How do changes in the daily food and transportation environments affect grocery store accessibility? Applied Geography, 83, 46-62. https://doi.org/10.1016/j.apgeog.2017.03.018

Wu, S. S., Kuang, H., \& Lo, S. M. (2018). Modeling shopping center location choice: shopper preference-based competitive location model. Journal of Urban Planning and Development, 145(1), 1-20.

https://doi.org/10.1061/(ASCE)UP.1943-5444.0000482

Wu, Y., Wu, C., Zhou, J., Zhang, B., Xu, C., Yan, Y., \& Liu, F. (2019). A DEMATEL-TODIM based decision framework for $\mathrm{PV}$ power generation project in expressway service area under an intuitionistic fuzzy environment. Journal of Cleaner Production, 247, 119099.

https://doi.org/10.1016/j.jclepro.2019.119099

Yang, Y., Roehl, W. S., \& Huang, J. H. (2017). Understanding and projecting the restaurantscape: the influence of neighborhood sociodemographic characteristics on restaurant location. International Journal of Hospitality Management, 67, 33-45. https://doi.org/10.1016/j.ijhm.2017.07.005

Yap, J. Y. L., Ho, C. C., \& Ting, C. Y. (2019). A systematic review of the applications of multi-criteria decision-making methods in site selection problems. Built Environment Project and Asset Management, 9(4), 548-563. https://doi.org/10.1108/BEPAM-05-2018-0078

Yıldız, N., \& Tüysüz, F. (2019). A hybrid multi-criteria decision making approach for strategic retail location investment: application to Turkish food retailing. Socio-Economic Planning and Science, 68, 100619.

https://doi.org/10.1016/j.seps.2018.02.006

Zhai, S., Xu, S., Yang, L., Zhou, M., Zhang, L., \& Qiu, B. (2015). Mapping the popularity of urban restaurants using social media data. Applied Geography, 63, 113-120.

https://doi.org/10.1016/j.apgeog.2015.06.006

Zhuang, Z. Y., Chiang, I. J., Su, C. R., \& Chen, C. Y. (2017). Modelling the decision of paper shredder selection using analytic hierarchy process and graph theory and matrix approach. Advances in Mechanical Engineering, 9(12), 1-11. https://doi.org/10.1177/1687814017737668

Zhuang, Z. Y., Lin, C. C., Chen, C. Y., \& Su, C. R. (2018a). Rank-based comparative research flow benchmarking the effectiveness of AHP-GTMA on aiding decisions of shredder selection by reference to AHP-TOPSIS. Applies Science, 8(10), 1974. https://doi.org/10.3390/app8101974

Zhuang, Z. Y., Su, C. R., \& Chang, S. C. (2019). The effectiveness of IF-MADM (intuitionistic-fuzzy multi-attribute decision-making) for group decisions: methods and an empirical assessment for the selection of a senior centre. Technological and Economic Development of Economy, 25(2), 322-364. https://doi.org/10.3846/tede.2019.8399

Zhuang, Z. Y., Yang, L. W., Lee, M. H., \& Wang, C. Y. (2018b). 'MEAN+R': implementing a web-based, multi-participant decision support system using the prevalent MEAN architecture with $\mathrm{R}$ based on a revised intuitionistic-fuzzy multiple attribute decision-making model. Microsystem Technologies, 24(3), 4291-43093. https://doi.org/10.1007/s00542-018-3755-z 


\section{Appendix}

Appendix A. Questionnaire sent to experts

\section{Questionnaire exploring the location determinants of Bubble Tea Shop (BTS)}

Hello! Thank you for kindly participating in this survey, titled "Questionnaire on exploring the location determinants of Bubble Tea Shop (BTS)." The world-famous "bubble milk tea" originated in Taiwan, and has been Asia's representative beverage globally. This questionnaire mainly explores the relationship between a BTS' location determinants and to evaluate three alternative shop locations in Najing, China.

Your opinion will provide relevant analysis (for only for academic purposes), and will not be disclosed or used for other means. The content of the questionnaire must be strictly confidential. Please feel free to answer the questions below. We appreciate your participation in this study.

\section{Part 1. Experts' information (Single choice, please fill in the relevant part)}

\section{a. Academic Sector}

1. Department: $\square$ Land management $\square$ Business management $\square$ Other

2. Position:

3. Working year:

b. Industry sector

1. Department: $\square$ Catering $\square$ Restaurant $\square$ BTS $\square$ Other

2. Position:

3. Working year:

c. Proposed evaluation framework for location determinants of BTS (Please read this table)

\begin{tabular}{|c|c|c|}
\hline Dimension & Criteria & Description \\
\hline \multirow[t]{3}{*}{$\begin{array}{l}\text { Traffic traits } \\
\left(D_{1}\right)\end{array}$} & $\begin{array}{l}\text { proximity to public } \\
\text { transportation system } \\
\left(C_{1}\right)\end{array}$ & $\begin{array}{l}\text { Shops with more subway stations and a larger number of bus lines within a certain } \\
\text { range have better accessibility to transportation, and will likely attract more potential } \\
\text { customers }\end{array}$ \\
\hline & $\begin{array}{l}\text { proximity to a street } \\
\text { corner }\left(C_{2}\right)\end{array}$ & Shops near a street corner will likely attract more potential customers \\
\hline & road width $\left(C_{3}\right)$ & $\begin{array}{l}\text { Shop facing a wide road will likely attract more potential customers as more vehicles } \\
\text { and pedestrians are likely to pass }\end{array}$ \\
\hline \multirow[t]{5}{*}{$\begin{array}{l}\text { Site traits } \\
\left(D_{2}\right)\end{array}$} & $\begin{array}{l}\text { proximity to public } \\
\text { facilities }\left(C_{4}\right)\end{array}$ & $\begin{array}{l}\text { Shops near community centers, arts and cultural centers, stadiums and public libraries will } \\
\text { likely attract more potential consumers and expand its range via food delivery systems }\end{array}$ \\
\hline & $\begin{array}{l}\text { proximity to the } \\
\text { community }\left(C_{5}\right)\end{array}$ & $\begin{array}{l}\text { Shops located in, or near larger communities will likely attract more potential } \\
\text { consumers and expand its range via food delivery systems }\end{array}$ \\
\hline & $\begin{array}{l}\text { proximity to } \\
\text { commercial areas }\left(C_{6}\right)\end{array}$ & $\begin{array}{l}\text { Shops located in, or near larger commercial areas will likely attract more potential } \\
\text { consumers and expand its range via food delivery systems }\end{array}$ \\
\hline & $\begin{array}{l}\text { proximity to schools } \\
\left(C_{7}\right)\end{array}$ & $\begin{array}{l}\text { Shops located in school areas, such as University towns or near larger schools, will } \\
\text { likely attract more potential consumers and expand its range via food delivery systems }\end{array}$ \\
\hline & $\begin{array}{l}\text { agglomeration effect } \\
\left(C_{8}\right)\end{array}$ & $\begin{array}{l}\text { Although areas with more BTSs may indicate a risk of competition, it is more likely } \\
\text { attract more potential consumers and expand its range via food delivery systems as } \\
\text { agglomeration can aid customers in choosing their beverage based on different tastes } \\
\text { and the atmosphere of the area/store }\end{array}$ \\
\hline \multirow[t]{5}{*}{$\begin{array}{l}\text { Shop traits } \\
\left(D_{3}\right)\end{array}$} & types of shop $\left(C_{9}\right)$ & $\begin{array}{l}\text { Two types of shop, including the street shop and shop in a department store, need to be } \\
\text { considered. Street stores attract more passers-by, while shops in commercial complexes } \\
\text { attract more consumer and expand its range via food delivery systems }\end{array}$ \\
\hline & sizes of shop $\left(C_{10}\right)$ & $\begin{array}{l}\text { A shop's size must be able to support various usage needs, such as shaking tea, brewing } \\
\text { tea, and storage of raw materials. The new generation of BTS may provide more seats in } \\
\text { the store, and a larger size may thus be required }\end{array}$ \\
\hline & rent $\left(C_{11}\right)$ & $\begin{array}{l}\text { Shops may incur a higher rent due to better transportation and location conditions, } \\
\text { larger size, or visibility }\end{array}$ \\
\hline & business hours $\left(C_{12}\right)$ & $\begin{array}{l}\text { Shops with longer business hours have more time to supply tea to consumers and are } \\
\text { located in business districts with similarly long total business hours }\end{array}$ \\
\hline & visibility $\left(C_{13}\right)$ & $\begin{array}{l}\text { Shops with strong visibility, such as those located at the core of the main street or } \\
\text { commercial complex, will increase their visibility and will be enhanced via billboard } \\
\text { advertisements }\end{array}$ \\
\hline
\end{tabular}




\section{Part 2. Evaluation form for influential relationships between 13 criteria}

\section{a. Instructions for completing the questionnaire (Please} read these instructions)

This part is mainly designed as an evaluation scale with a five-point isometric evaluation scale: no impact (0); small impact (1); medium impact (2); large impact (3); large impact (4). If you consider that factor A has a higher impact on criteria B (solid line in schematic diagram below), 4 points may be appropriate. If factor B has a medium impact upon factor A (dashed line in schematic diagram below), giving 2 points is reasonable. At the same time, the influential relationship between A and B can be equal,_and the slash grid does not need to be filled out.

\section{b. Evaluation form for 13 criteria (Please fill in the rel- evant sections)}

Please fill in the scores in the following spaces: no impact (0); little impact (1); little-to-medium impact (2); medium impact (3); large impact (4).

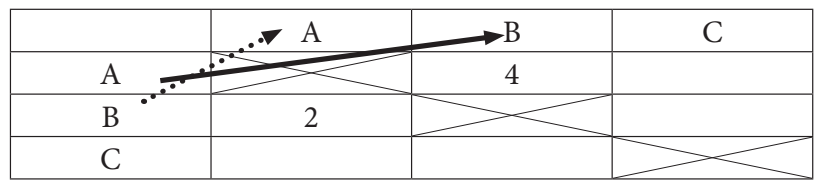

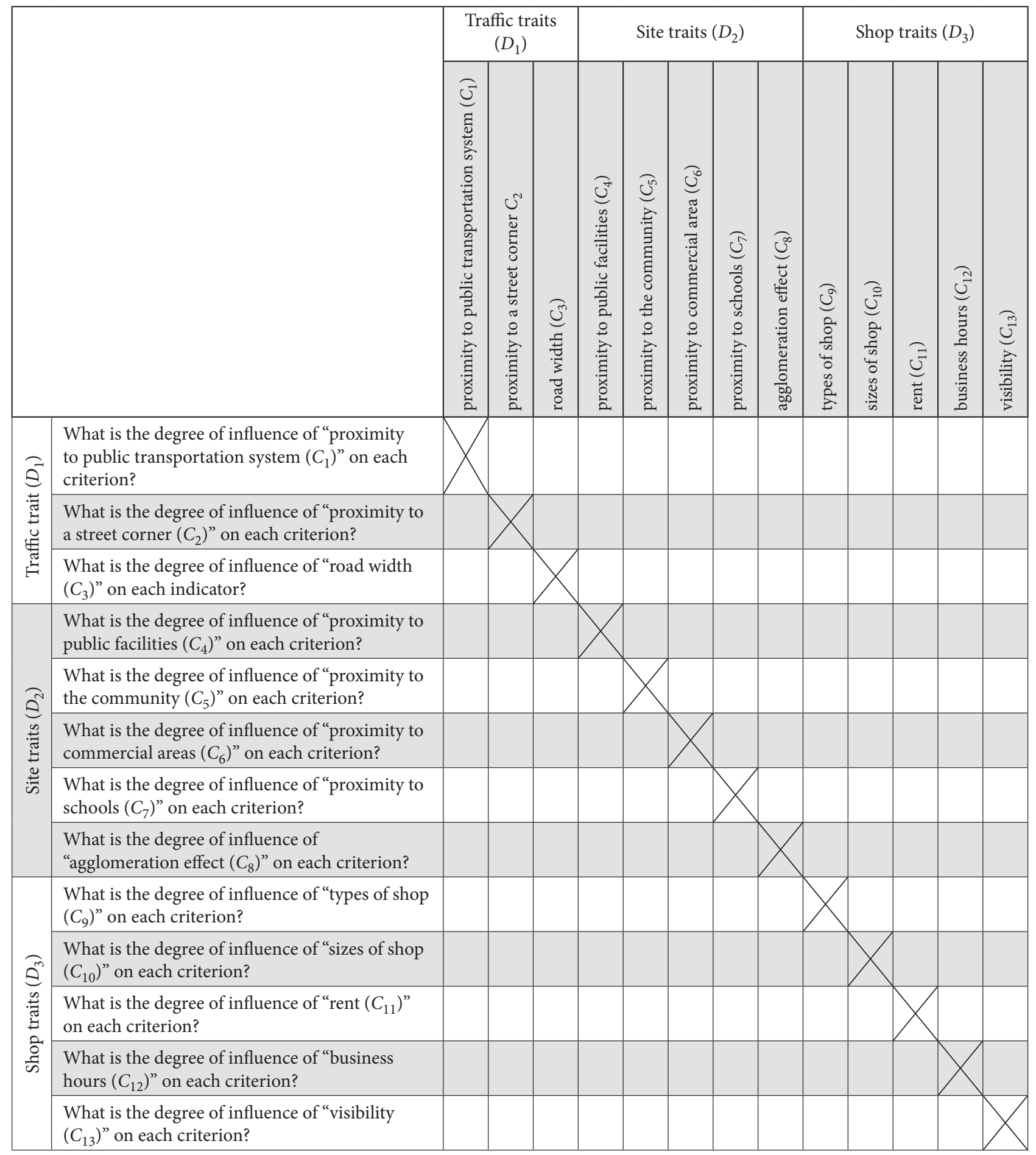




\section{Part 3. Evaluation form for three alternative shops found in Nanjing, China}

\section{a. Description of each criterion of the three alternative shops located in Nanjing (Please read this table)}

\begin{tabular}{|c|c|c|c|c|}
\hline Dimension & Criteria & Alternative A & Alternative B & Alternative C \\
\hline \multicolumn{2}{|l|}{ Area } & $\begin{array}{l}\text { Xuezelu commercial area in } \\
\text { Xianlin University Town, Qixia } \\
\text { District }\end{array}$ & $\begin{array}{l}\text { Xuezelu commercial area in Xianlin } \\
\text { University Town, Qixia District }\end{array}$ & $\begin{array}{l}\text { Xinjiekou Commercial District in } \\
\text { Qinhuai District }\end{array}$ \\
\hline \multirow[t]{3}{*}{$\begin{array}{l}\text { Traffic traits } \\
\left(D_{1}\right)\end{array}$} & $\begin{array}{l}\text { proximity } \\
\text { to public } \\
\text { transportation } \\
\text { system }\left(C_{1}\right)\end{array}$ & $\begin{array}{l}200 \text { meters away from Xueze } \\
\text { Road Station of MRT Line 2, } \\
\text { and near } 5 \text { bus lines passing by }\end{array}$ & $\begin{array}{l}150 \text { meters away from Xinjiekou } \\
\text { Metro Station of MRT } 1 \text { and 2; the } \\
\text { nearest bus stop has } 3 \text { bus lines } \\
\text { passing by }\end{array}$ & $\begin{array}{l}\text { Near the construction of } \\
\text { Hongyang Plaza Station of Metro } \\
\text { Line S8; } 2 \text { bus lines passing by }\end{array}$ \\
\hline & $\begin{array}{l}\text { proximity to a } \\
\text { street corner }\left(C_{2}\right)\end{array}$ & $\begin{array}{l}250 \text { meters away from the } \\
\text { intersection of Xueze Road and } \\
\text { Xianlin Avenue }\end{array}$ & $\begin{array}{l}50 \text { meters away from the intersection } \\
\text { of Shigu Road and Rich Road }\end{array}$ & $\begin{array}{l}50 \text { meters from the entrance of } \\
\text { B1 in shopping mall }\end{array}$ \\
\hline & road width $\left(C_{3}\right)$ & $\begin{array}{l}\text { The shop is in the food court, so } \\
\text { the road is only } 6 \text { meters wide } \\
\text { and only pedestrians can pass }\end{array}$ & $\begin{array}{l}\text { The shop faces Shigu Road, which is } \\
\text { about } 18 \text { meters wide and can be used } \\
\text { by vehicles and pedestrians }\end{array}$ & $\begin{array}{l}\text { The shop is not facing the main } \\
\text { arterial roads of the mall and can } \\
\text { only be accessed by pedestrians }\end{array}$ \\
\hline \multirow[t]{5}{*}{$\begin{array}{l}\text { Site traits } \\
\left(D_{2}\right)\end{array}$} & $\begin{array}{l}\text { proximity to } \\
\text { public facilities } \\
\left(C_{4}\right)\end{array}$ & $\begin{array}{l}\text { Located nearby and can deliver } \\
\text { via the food delivery system, } \\
\text { including (1) Government } \\
\text { agency: the Xianlin Office of the } \\
\text { Qixia District Government }\end{array}$ & $\begin{array}{l}\text { Located nearby and can deliver via } \\
\text { the food delivery system, including } \\
\text { (1) Popular tourist attractions: } \\
\text { Xuanwu Lake, Chaotian Palace, } \\
\text { Presidential Palace, Confucius Temple } \\
\text { Scenic Area, Jiangsu Provincial Art } \\
\text { Museum, Nanjing Library, Nanjing } \\
\text { Museum, Nanjing Geological } \\
\text { Museum, Nanjing Folk Customs } \\
\text { Museum (Ganxi House), Pilu } \\
\text { Temple, Jinling Carvings, Zijin Grand } \\
\text { Theater; (2) Large parks: Bailuzhou } \\
\text { Park, Xianmen Site Park and } \\
\text { Dongshuiguan Site Park; (3) Sports } \\
\text { Center: Wutaishan Sports Center, } \\
\text { Qinhuai Sports Center, Jiangsu } \\
\text { Province }\end{array}$ & $\begin{array}{l}\text { Located nearby and can delivered } \\
\text { via the food delivery system, } \\
\text { including (1) Government } \\
\text { agency: the Taishan Sub-district } \\
\text { Office; (2) Passenger Station: } \\
\text { Nanjing Long-distance Bus } \\
\text { Station, Jiangbei Passenger } \\
\text { Transport Department; (3) Large- } \\
\text { scale parks: Qiaobei Riverside } \\
\text { Ecological Park, Baotashan Forest } \\
\text { Park, Liuzhou Xiaoyou Park; (4) } \\
\text { Sports Center: Pukou Culture } \\
\text { and Sports Center }\end{array}$ \\
\hline & $\begin{array}{l}\text { proximity to the } \\
\text { community }\left(C_{5}\right)\end{array}$ & $\begin{array}{l}\text { Located near the Yadong } \\
\text { community, the Kangqiao Santa } \\
\text { Fe community, and a total of } 24 \\
\text { residential communities can be } \\
\text { reached via the food delivery } \\
\text { system }\end{array}$ & $\begin{array}{l}\text { A total } 285 \text { small and medium } \\
\text { residential communities can be } \\
\text { reached via the food delivery system }\end{array}$ & $\begin{array}{l}\text { A total } 64 \text { residential } \\
\text { communities can be reached via } \\
\text { the food delivery system, and } \\
\text { includes larger communities } \\
\text { (such as } 19 \text { blocks in the } \\
\text { Venice communities and } 16 \\
\text { blocks in the Huaning Tianrun } \\
\text { Ccommunities }\end{array}$ \\
\hline & $\begin{array}{l}\text { proximity to } \\
\text { commercial areas } \\
\left(C_{6}\right)\end{array}$ & $\begin{array}{l}\text { A total of } 11 \text { shopping malls, } \\
\text { commercial offices and } \\
\text { industrial zones - including } \\
\text { Rand Information Industry } \\
\text { Park, Suning Headquarters - can } \\
\text { be reached via the food delivery } \\
\text { system }\end{array}$ & $\begin{array}{l}\text { A total of } 128 \text { shopping malls, } \\
\text { commercial offices and industrial } \\
\text { zones - including Deji Mall, Ocean } \\
\text { Department Store, Central Mall and } \\
\text { Golden Eagle Department Store - } \\
\text { can be reached via the food delivery } \\
\text { system }\end{array}$ & $\begin{array}{l}\text { A total of } 15 \text { Shopping malls, } \\
\text { commercial offices and industrial } \\
\text { zones - including Xiaoliu } \\
\text { Industrial Zone in Nanjing High- } \\
\text { tech Zone, Nanjing Railway } \\
\text { Logistics Base of China Railway, } \\
\text { Baotashan Creative Industry } \\
\text { Park - can be reached via the } \\
\text { food delivery system }\end{array}$ \\
\hline & $\begin{array}{l}\text { proximity to } \\
\text { schools }\left(C_{7}\right)\end{array}$ & $\begin{array}{l}\text { More than } 10 \text { universities and } \\
\text { colleges, and more than } 10 \\
\text { primary and secondary schools }\end{array}$ & $\begin{array}{l}10 \text { universities and colleges, and } \\
\text { more than } 30 \text { primary and secondary } \\
\text { schools are located nearby }\end{array}$ & $\begin{array}{l}2 \text { colleges and } 8 \text { primary and } \\
\text { secondary schools are nearby }\end{array}$ \\
\hline & $\begin{array}{l}\text { agglomeration } \\
\text { effect }\left(C_{8}\right)\end{array}$ & $\begin{array}{l}\text { There are } 19 \text { BTSs within a } \\
10 \text {-minute walk (approximately } \\
600 \text { meters) of this area, and } 40 \\
\text { BTSs within the delivery range } \\
\text { for food delivery systems }\end{array}$ & $\begin{array}{l}\text { There are } 51 \text { BTSs within a } 10 \text {-minute } \\
\text { walk, and there are } 424 \text { BTSs within } \\
\text { the delivery range for food delivery } \\
\text { systems }\end{array}$ & $\begin{array}{l}\text { There are } 17 \text { BTSs within a } \\
\text { 10-minute walk, and there are } 53 \\
\text { BTSs within the delivery range } \\
\text { for food delivery systems }\end{array}$ \\
\hline \multirow[t]{5}{*}{ Shop traits $\left(D_{3}\right)$} & types of shop $\left(C_{9}\right)$ & $\begin{array}{l}\text { Street shop on first floor of the } \\
\text { horizontal food court }\end{array}$ & Traditional street shop & $\begin{array}{l}\text { Street store in B1 of shopping } \\
\text { mall }\end{array}$ \\
\hline & sizes of shop $\left(C_{10}\right)$ & 20 square meters & 15 square meters & 15 square meters \\
\hline & $\operatorname{rent}\left(C_{11}\right)$ & $\begin{array}{l}\text { Monthly rent is RMB } 16,600 \\
\text { (RMB 830/square meter) }\end{array}$ & $\begin{array}{l}\text { Monthly rent is approximately RMB } \\
25,833 \text { (RMB } 1,722 / \text { square meter) }\end{array}$ & $\begin{array}{l}\text { Monthly rent is approximately } \\
\text { RMB 10,000 (RMB 667/ square } \\
\text { meter) }\end{array}$ \\
\hline & \begin{tabular}{|l} 
business hours \\
$\left(C_{12}\right)$
\end{tabular} & $\begin{array}{l}\text { Operates from Monday to } \\
\text { Sunday between } 10 \text { am to } 10 \mathrm{pm}\end{array}$ & $\begin{array}{l}\text { Operates from Monday to Sunday } \\
\text { between } 10 \text { am to } 10 \mathrm{pm}\end{array}$ & $\begin{array}{l}\text { Operates from Monday to Sunday } \\
\text { between } 10 \mathrm{am} \text { and } 10 \mathrm{pm}\end{array}$ \\
\hline & visibility $\left(C_{13}\right)$ & $\begin{array}{l}\text { Because it is not on the main } \\
\text { road, it is impossible to directly } \\
\text { see the shop sign }\end{array}$ & $\begin{array}{l}\text { It is located on Shigu Road, the shop } \\
\text { sign can be viewed directly }\end{array}$ & $\begin{array}{l}\text { It is not at the core of department } \\
\text { store, its store sign can only be } \\
\text { seen at the entrance }\end{array}$ \\
\hline
\end{tabular}


b. Evaluation form for the three alternatives (Please fill in the relevant sections)

Please indicate your satisfaction with the 13 criteria in terms of each alternative in the table below. If you are most satisfied with "Proximity to public transportation systems $\left(C_{1}\right)$," please insert 10 points; if you are not satisfied, fill in 1.

\begin{tabular}{|c|c|c|c|c|}
\hline \multirow[t]{2}{*}{ Dimensions } & \multirow[t]{2}{*}{ Criteria } & \multicolumn{3}{|c|}{$\begin{array}{c}\text { Evaluation } \\
(\text { very unsatisfied } \leftarrow 1,2, \ldots, 9,10 \rightarrow \text { very satisfied })\end{array}$} \\
\hline & & A & B & $\mathrm{C}$ \\
\hline \multirow{3}{*}{$\begin{array}{l}\text { Traffic traits } \\
\left(D_{1}\right)\end{array}$} & proximity to public transportation system $\left(C_{1}\right)$ & & & \\
\hline & proximity to a street corner $\left(C_{2}\right)$ & & & \\
\hline & road width $\left(C_{3}\right)$ & & & \\
\hline \multirow{5}{*}{$\begin{array}{l}\text { Site traits } \\
\left(D_{2}\right)\end{array}$} & proximity to public facilities $\left(C_{4}\right)$ & & & \\
\hline & proximity to the community $\left(C_{5}\right)$ & & & \\
\hline & proximity to commercial areas $\left(C_{6}\right)$ & & & \\
\hline & proximity to schools $\left(C_{7}\right)$ & & & \\
\hline & agglomeration effect $\left(C_{8}\right)$ & & & \\
\hline \multirow[t]{5}{*}{ Shop traits $\left(D_{3}\right)$} & types of shop $\left(C_{9}\right)$ & & & \\
\hline & sizes of shop $\left(C_{10}\right)$ & & & \\
\hline & rent $\left(C_{11}\right)$ & & & \\
\hline & business hours $\left(C_{12}\right)$ & & & \\
\hline & visibility $\left(C_{13}\right)$ & & & \\
\hline
\end{tabular}

Appendix B. MADM model

\section{B.1 Modeling procedure for DEMATEL}

(1) First step: The initial influential relation matrix $M_{\text {initial }}$ is constructed, in which $a_{i j}$ indicates the degree of influence of one certain criterion $i$ on another criterion $j$, and $n$ represents the criteria selected:

$$
M_{\text {initial }}=\left[a_{i j}\right]_{n \times n} .
$$

(2) Second step: $M_{\text {initial }}$ is divided by the sum of each row and each column to obtain a normalized influence relation matrix $M_{\text {nmlinitial }}$ :

$$
M_{\text {nmlinitial }}=k A \text {, }
$$

where $k=\min \left\{1 / \max _{i} \sum_{j=1}^{n} a_{i j}, 1 / \max _{i} \sum_{i=1}^{n} a_{i j}\right\}$.

(3) Third step: Then, $M_{\text {nmlinitial }}$ after power processing (i.e. $\lim _{h \rightarrow \infty} M_{n \text { mlinitial }}^{k}=[0]_{n \times n}$ ) obtains the total influence relationship matrix for criteria $M_{c}$ is obtained:

$$
M_{c}=M_{n m l i n i t i a l}\left(I-M_{n m l i n i t i a l}\right)^{-1} .
$$

After that, each row and column are summed up respectively to get the sum vector of the row $d$ and the sum vector of the column $r$, in which superscript ' represents transposition:

$$
\begin{aligned}
& d=\left[\sum_{i=1}^{n} t_{i j}\right]_{n \times 1}=\left[d_{i}\right]_{n \times 1} ; \\
& r=\left[\sum_{i=1}^{n} t_{i j}\right]_{n \times 1}^{\prime}=\left[r_{i}\right]_{n \times 1}^{\prime} .
\end{aligned}
$$

\section{B.2 Modeling procedure for DANP}

(1) First step: The first step is to normalize the $M_{c}$ obtained by DEMATEL (Eq. A.3) for getting the normalized total influence relation matrix $M_{n m l c}$ :

$$
M_{n m l c}=\left[\begin{array}{ccc}
M_{n m l c}^{11} & M_{n m l c}^{1 j} & M_{n m l c}^{1 p} \\
M_{n m l c}^{i 1} & M_{n m l c}^{i j} & M_{n m l c}^{i p} \\
M_{n m l c}^{p 1} & M_{n m l c}^{p j} & M_{n m l c}^{p p}
\end{array}\right]_{n \times n \mid q<n, \Sigma_{j=1}^{p} p_{j}=n}
$$

Following way that obtain $M_{c}$, the total influence relationship matrix for dimension $M_{d}$ is normalized and then obtain the normalized influence relationship matrix for dimension $M_{n m l d}$, as follows:

$$
M_{n m l d}=\left[\begin{array}{ccc}
M_{n m l d}^{11} & M_{n m l d}^{1 j} & M_{n m l d}^{1 p} \\
M_{n m l d}^{i 1} & M_{n m l d}^{i j} & M_{n m l d}^{i p} \\
M_{n m l d}^{p 1} & M_{n m l d}^{p j} & M_{n m l d}^{p p}
\end{array}\right]_{n \times n \mid q<n, \Sigma_{j=1}^{p} p_{j}=n}
$$

(2) Second step: $M_{n m l c}$ is transposed to get the unweighted super-matrix $W_{u n w}=\left(M_{n m l c}\right)^{\prime}$. Traditional ANP indicated the blank or 0 shown in the $W_{n m l w}^{p p}$ :

$$
W_{n m l w}=\left(M_{n m l c}\right)^{\prime}=\left[\begin{array}{ccc}
W_{n m l w}^{11} & W_{n m l w}^{i 1} & W_{n m l w}^{p 1} \\
W_{n m l w}^{1 j} & W_{n m l w}^{i j} & W_{n m l w}^{p j} \\
W_{n m l w}^{1 p} & W_{n m l w}^{i p} & W_{n m l w}^{p p}
\end{array}\right]
$$


Then, $M_{n m l d}$ is also introduced into $W_{u n w}=\left(M_{n m l c}\right)^{\prime}$ for obtaining the weighted super-matrix $W_{w s w}=M_{n m l d} W_{u n w}$ :

$$
W_{w s w}=M_{n m l d} W_{u n w}=\left[\begin{array}{ll}
M_{n m l d}^{11} \times W_{n m l w}^{11} & M_{n m l d}^{1 j} \times W_{n m l w}^{i 1} \\
M_{n m l d}^{i 1} \times W_{n m l w}^{1 j} & M_{n m l d}^{i j} \times W_{n m l w}^{i j} \\
M_{n m l d}^{p 1} \times W_{n m l w}^{1 p} & M_{n m l d}^{p j} \times W_{n m l w}^{i p}
\end{array}\right.
$$

where $M_{n m l d}^{i j}$ is a scalar and $\sum_{j=1}^{p} p_{j}=n$.

(3) Third step: According to the concept of Markov chain, the weighted super-matrix $W_{w s w}$ is multiplied by a hundred times to obtain a finite super-matrix as follow:

$$
W_{D A N P}=\lim _{\varphi \rightarrow \infty}\left(W_{w s w}\right)^{\varphi} \text {. }
$$

In other words, the weighted super-matrix is limited by $\varphi$ power of $W_{w s w}$ meaning super-matrix should converge and become a stable super-matrix in long term if it is larger enough, and hence obtaining the weight of DANP $W_{D A N P}$.

\section{B.3 Modeling procedure for modified VIKOR}

(1) First step: The potential alternative performance matrix $A_{j}$ is established based on opinion of experts, in which $k$ represents the three alternative number in this study:

$$
A_{j}=\left[f_{k j}\right]_{k \times n} .
$$

(2) Second step: The $S_{k}$ and $Q_{k}$ is indicated to represent the average GAP with aspiration level and the maximum GAP with the aspiration level, respectively. $W_{D A N P}$ represents the local weight of the DANP:

$$
\begin{aligned}
& S_{k}=L_{k}^{A=1}=\sum_{j=1}^{n}\left[w_{j}\left(\frac{\left|f_{j}^{\text {aspire }}-f_{k j}\right|}{\left|f_{j}^{\text {aspire }}-f_{j}^{-}\right|}\right)\right] ; \\
& Q_{k}=L_{k}^{p=\infty}=\max _{j}\left\{\frac{\left|f_{j}^{\text {aspire }}-f_{k j}\right|}{\left|f_{j}^{\text {aspire }}-f_{j}^{-}\right|} \mid j=1,2, \cdots, n\right\} .
\end{aligned}
$$

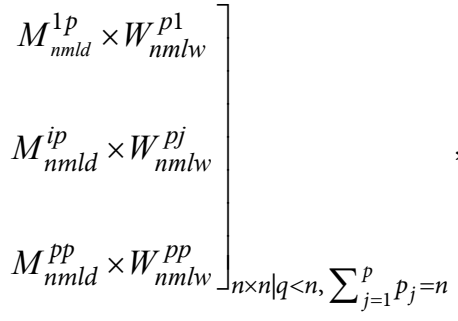

(3) Third step: Integration index $R_{k}$ is obtained based on the principle of a minimum integration GAP, i.e. $\min _{k} L_{k}^{P}$.

$$
R_{k}=v \frac{\left(S_{k}-S^{\text {aspire }}\right)}{\left(S^{-}-S^{\text {aspire }}\right)} /+(1-v) \frac{\left(Q_{k}-Q^{\text {aspire }}\right)}{\left(Q^{-}-Q^{\text {aspire }}\right)} \text {. }
$$

In this study, the group benefits (i.e. utilizing the maximum group utility $\min _{k} S_{k}$ ) will be highlighted when $p$ is smallest (i.e. $p=1$ ). Hence, $S^{\text {aspire }}=\min _{k} S_{k}$ (i.e. $\left.S^{\text {aspire }}=0\right), S^{-}=\max _{k} S_{k}$ (i.e. $S^{-}=1$ ). Then, $R_{k}$ is equal to as follows:

$$
R_{k}=v S_{k}+(1-v) Q_{k},
$$

where $v$ is trade-off parameter for decision-making. This value can allow the decision maker to judge the intergrade value $R_{k}$ in different decision-making situations. When $v$ is greater than 0.5 , it means that the decision maker is more inclined to adopt a "maximal group utility strategy." Conversely, when $v$ is closer to zero, it indicates that the decision maker is more inclined to adopt the "maximum individual utility strategy. 